\title{
AS CAIXAS DE LIQUIDAÇÃO NO ÂMBITO DO SISTEMA DE PAGAMENTOS BRASILEIRO
}

\author{
DISSERTAÇÃO DE MESTRADO
}

Orientador: Professor Associado Haroldo Malheiros Duclerc Verçosa

FACULDADE DE DIREITO DA UNIVERSIDADE DE SÃO PAULO São Paulo - 2011 


\title{
AS CAIXAS DE LIQUIDAÇÃO NO ÂMBITO DO SISTEMA DE PAGAMENTOS BRASILEIRO
}

\author{
Dissertação apresentada na Faculdade de Direito \\ da Universidade de São Paulo, como requisito \\ parcial para a obtenção do título de Mestre em \\ Direito Comercial, sob orientação do Professor \\ Associado Haroldo Malheiros Duclerc Verçosa.
}

FACULDADE DE DIREITO DA UNIVERSIDADE DE SÃO PAULO

São Paulo - 2011 
Banca Examinadora 
Ao meu avô Gustavo, por tudo. 
"One's mind, once stretched by a new idea, never regains its original dimensions." Oliver Wendell Holmes 


\section{Agradecimentos}

Agradeço muito especialmente ao estimado Professor Haroldo Verçosa, não só pela orientação, mas pela amizade, confiança e por me abrir as portas de São Paulo ao me dar a oportunidade de ingressar nessa gloriosa Faculdade. Os resultados pessoal, acadêmico e profissional dessa experiência me tornam eternamente grato ao Professor Verçosa.

Agradeço ao Professor Marcos Paulo de Almeida Salles, pelos importantes ensinamentos e pelo contagiante entusiasmo pela ciência e pelo tema deste trabalho. No Professor Marcos Paulo personifico todos os meus mestres mais inspiradores, desde a mais longínqua idade.

Aos meus pais Ezequiel e Regina, pelo que sou, pelo que sei e, especialmente nesta fase do meu projeto de vida, pela certeza do porto seguro necessário ao desbravamento de caminhos desafiadores.

Por fim, agradeço à minha Mariana pelo companheirismo incondicional que alicerça minha jornada. 


\section{RESUMO}

A incessante busca do homem pela eficiência e sofisticação dos processos por ele manejados em todas as áreas do conhecimento, aliada aos grandes avanços tecnológicos das últimas décadas, tem gerado importantes alterações nos meios de pagamento e na sistemática de liquidação financeira de obrigações. Com o surgimento de mecanismos mais robustos de liquidação, estamos observando a substituição dos meios de pagamento em papel e das transações isoladas entre os indivíduos pela informatização da negociação e o aumento do raio de abrangência das caixas de liquidação. Este trabalho levanta o panorama histórico das câmaras de liquidação, traçando o estado da arte dessa figura no Brasil e suas principais questões jurídicas, também verificando sua aderência às melhores práticas experimentadas em mercados desenvolvidos.

\section{PALAVRAS-CHAVE}

caixas de liquidação, compensação, sistema de pagamentos brasileiro, meios de pagamento, liquidação eletrônica, títulos de crédito. 


\section{ABSTRACT}

Mankind's endless quest for efficiency and sophistication of the processes managed by the men in all areas of knowledge, coupled with major technological advances of recent decades, has generated important changes in payment methods and the clearing of financial obligations. With the emergence of more robust mechanisms of settlement, we are watching the replacement of paper-based payment methods and transactions between isolated individuals by the computerization of trading and the increase of the radius of coverage of the settlement institutions. This work traces the historical view of the clearing houses, outlining the state of the art of this figure in Brazil and its main legal issues, and checking if it complies with the best practices already experienced in developed markets.

\section{KEYWORDS}

clearing houses, settlement, brazilian payments system, payment instruments, electronic clearing, payment methods. 


\section{SUMÁRIO}

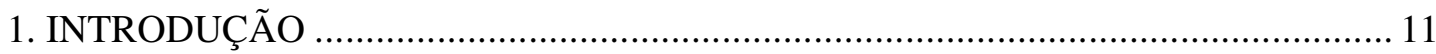

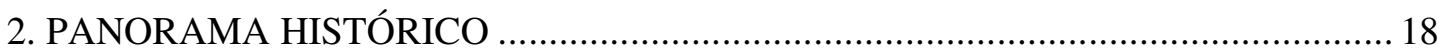

2.1. Meios alternativos de pagamento .................................................................... 19

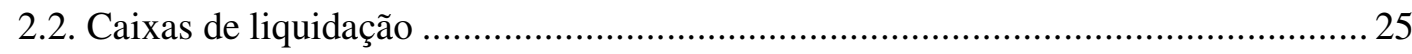

3. CONCEITUAÇÃO E ENQUADRAMENTO DO TEMA.............................................. 31

4. A DINÂMICA DE FUNCIONAMENTO E AS FUNÇÕES DAS CAIXAS DE

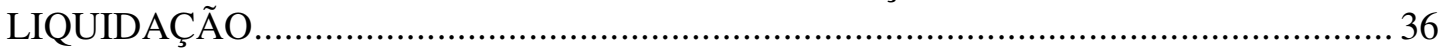

4.1. A dinâmica de funcionamento das caixas de liquidação........................................ 36

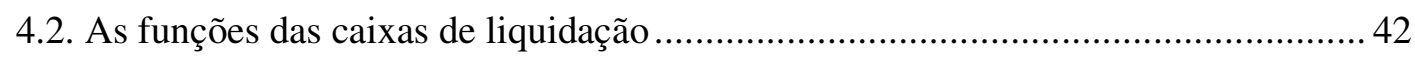

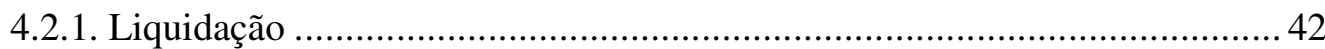

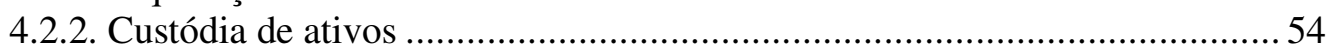

4.2.3. Gerenciamento de riscos e garantias ........................................................ 56

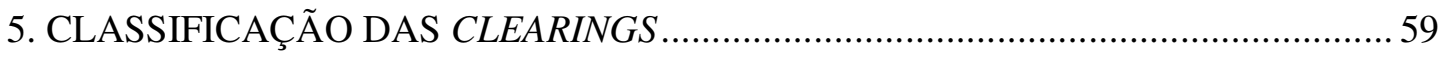

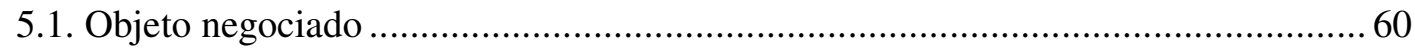

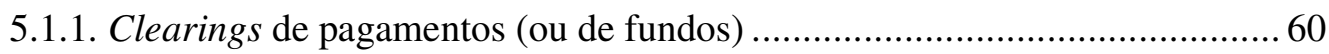

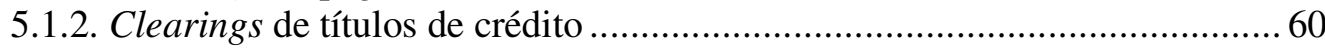

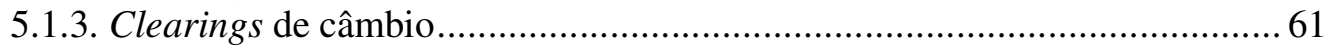

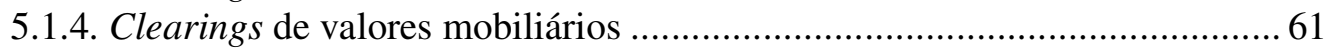

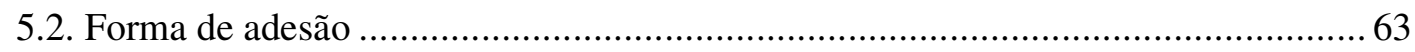

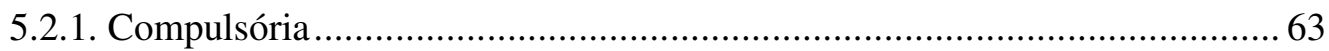

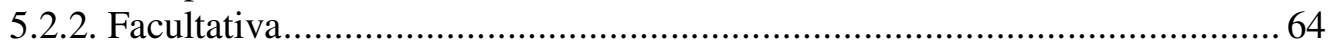

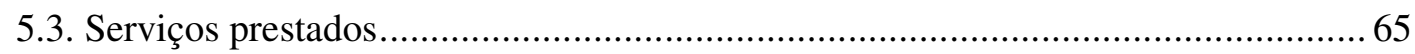

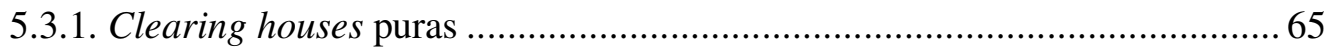

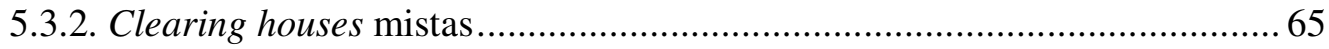

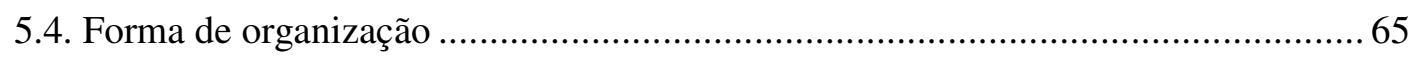

6. AS CLEARINGS NO SISTEMA DE PAGAMENTOS BRASILEIRO ........................67

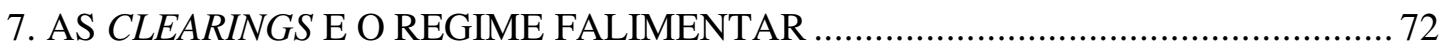

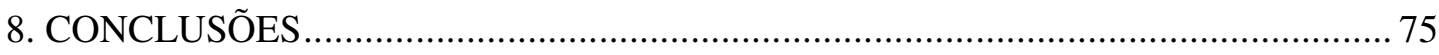

8.1. CONCLUSÃO A PARTIR DO DIREITO COMPARADO …............................. 75

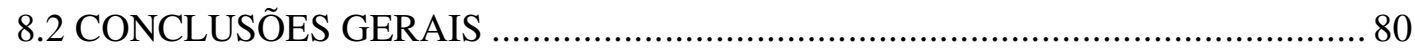

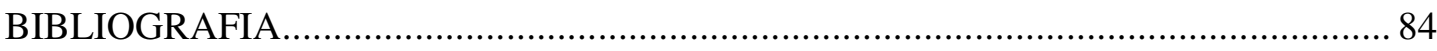




\section{ABREVIATURAS}

\begin{tabular}{|c|c|}
\hline $\mathrm{ABBC}$ & Associação Brasileira de Bancos \\
\hline ABBI & Associação Brasileira dos Bancos Internacionais \\
\hline ABECS & Associação Brasileira de Cartões de Crédito e Serviço \\
\hline ACREFI & Associação Nac. das Instituições de Crédito, Financiamento e Investimento \\
\hline BaCen & Banco Central do Brasil \\
\hline BIS & Bank for International Settlements \\
\hline CBLC & Câmara Brasileira de Liquidação e Custódia \\
\hline CIP & Câmara Interbancária de Pagamentos \\
\hline $\mathrm{CMN}$ & Conselho Monetário Nacional \\
\hline COMPE & Centralizadora da Compensação de Cheques \\
\hline CPMF & Contribuição Provisória sobre Movimentações Financeiras \\
\hline CVM & Comissão de Valores Mobiliários \\
\hline DOC & Documento de Ordem de Crédito \\
\hline FEBRABAN & Federação Brasileira de Bancos \\
\hline IBGE & Instituto Brasileiro de Geografia e Estatística \\
\hline IF & Instituição Financeira \\
\hline IOSCO & International Organization of Securities Commission \\
\hline PEA & População Economicamente Ativa \\
\hline PIB & Produto Interno Bruto \\
\hline RSFN & Rede do Sistema Financeiro Nacional \\
\hline SDTVM & Sistema de Distribuição de Títulos e Valores Mobiliários \\
\hline SELIC & Sistema Especial de Liquidação e Custódia \\
\hline SFN & Sistema Financeiro Nacional \\
\hline SCG & Sistema de Controle de Garantias \\
\hline SILOC & Sistema de Liq. Diferida das Transf. Interbancárias de Ordens de Crédito \\
\hline SITRAF & Sistema de Transferências de Fundos \\
\hline SPB & Sistema de Pagamentos Brasileiro \\
\hline STR & Sistema de Transferência de Reservas \\
\hline TED & Transferência Eletrônica Direta \\
\hline
\end{tabular}




\section{INTRODUÇÃO}

Hoje em dia é de se estranhar - e, por vezes, até de se suspeitar -, quando um negócio de compra e venda carrega consigo a condição de só poder ser realizado mediante troca de papel moeda ou título cambiariforme, sem a possibilidade de se lançar mão de meios eletrônicos de pagamento mais avançados, por assim dizer.

Registre-se, entretanto, que tal cenário não está tão distante dos dias atuais. Até meados do século XX, a inventividade humana ainda não tinha dado conta de criar meios de pagamento muito diferentes da moeda e de títulos representativos desta, materializados na sua forma mais tradicional: em papel.

Foram as últimas cinco décadas, especialmente esta que inaugurou o terceiro milênio, que assistiram a uma grande profusão de novidades em se tratando de meios de pagamento.

Uma pequena revolução nesse âmbito ocorreu com a criação do cartão de crédito $^{1}$, instrumento que possibilitou a realização de pagamentos sem a presença física de papel moeda ou título cambiariforme no momento da compra e venda.

Desde então, um sem número de outros meios de pagamento foram inventados ou aperfeiçoados, na medida em que o avanço tecnológico foi oferecendo novas possibilidades. Na atualidade, o que há de mais moderno e ainda acessível a poucos são os meios de pagamento contactless ${ }^{2}$ e os que se utilizam da biometria ${ }^{3}$.

É evidente que essas modalidades, além das que ainda estão em gestação e outras tantas que ainda nem foram pensadas, logo mais deixarão de ser novidade e cairão

\footnotetext{
1 SIENKIEWICZ, Stan. Credit Cards and Payment Efficiency. Federal Reserve Bank of Philadelphia. Discussion Paper. Agosto/2001. Disponível em: <http://www.philadelphiafed.org/payment-cardscenter/publications/discussion-papers/2001/PaymentEfficiency_092001.pdf>. Acesso em 1/12/2010.

${ }^{2}$ Sem contato físico entre o instrumento de pagamento e o dispositivo leitor portado pelo estabelecimento.

${ }^{3}$ Ao invés de usar um instrumento artificial (ex.: cartão de plástico), o indivíduo é identificado por alguma característica sua corporal única, como a íris e a impressão digital.
} 
no esquecimento da invisibilidade, ou seja, estarão tão incorporadas ao cotidiano que ninguém nem se dará conta da sua existência e complexidade.

Ou simplesmente cairão em desuso e serão lembradas como invenções pitorescas que não vingaram.

O fato notório é que a cada dia que passa os tradicionais meios de pagamento - neste trabalho assim considerados essencialmente o papel moeda e os títulos de crédito - estão sendo gradativamente menos utilizados, em detrimento de uma série de novos instrumentos.

Os dados estatísticos oficiais comprovam essa tendência. Segundo o Banco Central do Brasil ${ }^{4}$, entre 2003 e 2008 o uso de cheques caiu $36 \%$ em número de transações, enquanto o cartão de débito teve no mesmo período um incremento no mercado de pagamentos de $217 \%$. Seguindo a mesma direção, as transferências bancárias eletrônicas cresceram $90 \%$ e o cartão de crédito $133 \%$ nesse interregno.

O incremento no número de cartões emitidos no Brasil é igualmente expressivo. De acordo com a Associação Brasileira das Empresas de Cartões de Crédito e Serviços, em $2003^{5}$, havia 221 milhões de cartões em circulação no território nacional.

A projeção existente quando da elaboração deste trabalho dava conta de que até o final de $2010^{6}$, haveria algo em torno de 630 milhões de cartões de crédito emitidos no Brasil. Trata-se de um incremento de $185 \%$ em número de cartões, enquanto que, no mesmo período (2003-2010), a população brasileira aumentou em torno de $7 \%$ e a população economicamente ativa (PEA) em $10 \%{ }^{7}$.

\footnotetext{
${ }^{4}$ BACEN. Diagnóstico do Sistema de Pagamentos de Varejo no Brasil - Adendo Estatístico. 2008.

5 ABECS. Resumo de indicadores 2003/2004. Disponível em: <http://www.abecs.org.br/novo_site/ arquivos\%20excel/Tabela_Resumida_2004.pdf>. Acesso em 15/11/2010.

6 ABECS. Indicadores mensais 2010. Disponível em: <http://www.abecs.org.br/novo_site/ arquivos\%20excel/Mensal_2010_Consolidado.pdf>. Acesso em 27/12/2010.

${ }^{7}$ De acordo com a metodologia da Pesquisa Mensal de Emprego, realizada pelo IBGE na área urbana de seis regiões metropolitanas: Recife, Salvador, Belo Horizonte, Rio de Janeiro, São Paulo e Porto Alegre.
} 


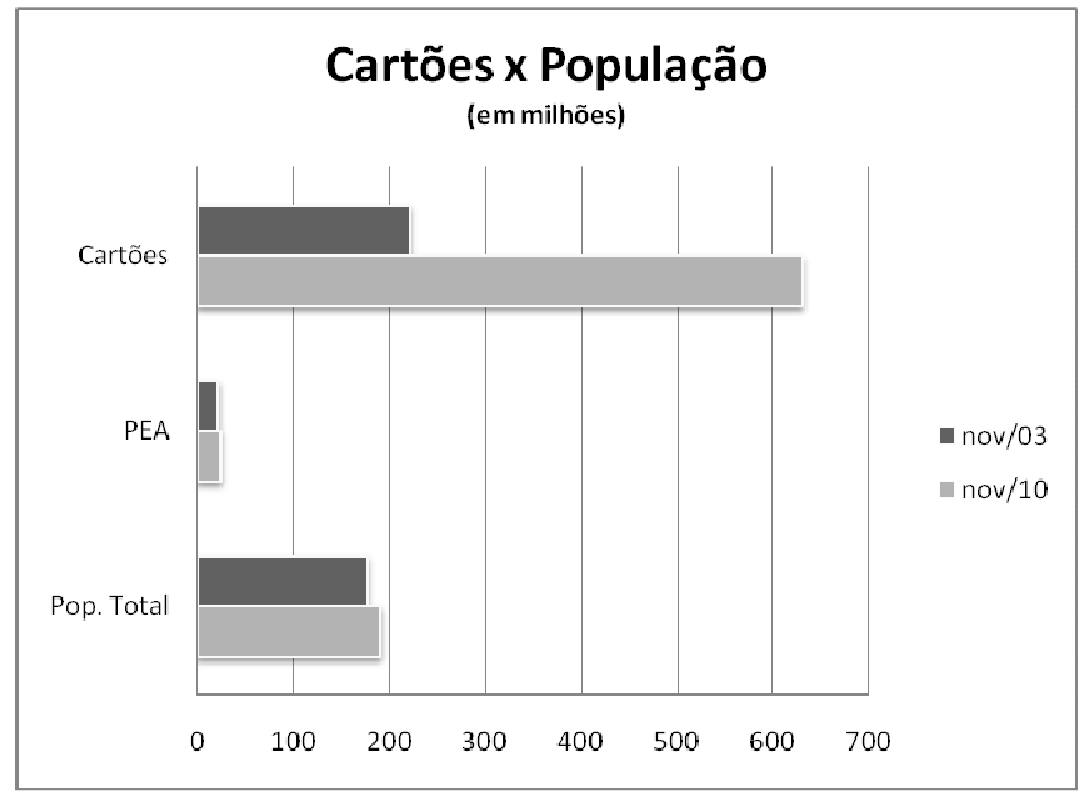

Fonte: IBGE $2003^{8}$ e IBGE $2010^{9}$.

Ainda que tais números precisem ser cotejados em conjunto com outros parâmetros e critérios para que se tenha uma análise econômica mais aprofundada - o que foge do escopo deste trabalho -, a grandiosidade da disparidade de crescimento exposto no gráfico acima é espantosa e demonstra que há, no mínimo, um movimento muito importante em curso. O dinheiro eletrônico é uma realidade.

Mas, se de um lado a experiência cotidiana permite inferir que a utilização de meios eletrônicos de pagamento já é fato comum incorporado ao dia a dia de grande parte das pessoas físicas e à quase totalidade dos empresários, de outro se sabe que poucos estudos jurídicos aprofundaram a análise de determinados aspectos e institutos dessa nova realidade.

É evidente que muitos conceitos que servem de base aos meios eletrônicos de pagamento nada mais são que velhos institutos numa nova roupagem. Ou simplesmente novas espécies de antigos gêneros. Inclusive isso já foi objeto de importantes discussões no meio acadêmico.

8 IBGE. Estimativa populacional em 1/7/2003. Disponível em: <ftp://ftp.ibge.gov.br/ Estimativas_Projecoes_Populacao/Estimativas_2003/>. Acesso em 5/1/2011.

9 IBGE. Censo Demográfico 2010. Disponível em: <http://www.ibge.gov.br/servidor_arquivos_est/ diretorios.php?caminho=./pub/Censos/Censo_Demografico_2010\#>. Acesso em 5/1/2011. 
Há, entretanto, nesse mundo dos pagamentos eletrônicos, uma figura pouco explorada pela doutrina jurídica brasileira, ainda que essencialmente regulada pelo Direito: a caixa de liquidação ${ }^{10}$.

Da mesma forma que outros assuntos que aparentemente remetem só a cifras e cálculos, esse é mais um tema que costuma escapar do escopo dos estudos jurídicos e termina por ser delegado a economistas e especialistas das ciências exatas.

Como se verá, as caixas de liquidação, muito pelo contrário do que se possa imaginar à primeira vista, são constituídas de um intrincado feixe de relações jurídicas entre diversos agentes econômicos que, no mais das vezes, nem mesmo se conhecem ou tiveram contato um com o outro.

Tal feixe não é percebido pelas partes efetivamente contratantes, que normalmente enxergam uma só contraparte com quem acreditam estar negociando seus interesses.

Um exemplo muito claro disso é o das negociações no mercado bursátil, onde o comprador de determinado título mobiliário usualmente não faz idéia de quem é a sua contraparte vendedora. A se tirar pela dinâmica do mercado, ambos também não imaginam a intricada cadeia de operações que os separa.

É nesse contexto que a importância do presente trabalho se justifica, uma vez que, por mais que a liquidação eletrônica de obrigações pecuniárias esteja plenamente consolidada e absorvida enquanto fato social, há algumas questões ${ }^{11}$ cujo respaldo não encontra guarida direta e imediata na Ciência Jurídica, demandando, portanto, um estudo mais específico.

\footnotetext{
${ }^{10}$ No presente trabalho foi adotada de forma mais corriqueira a tradução "caixa de liquidação" para clearing house, mas ao longo do texto outras palavras/expressões sinônimas serão utilizadas, como "câmara de liquidação", "câmara de compensação", "liquidante" ou mesmo em Inglês - clearing (substantivo).

${ }^{11}$ Como a discussão acerca da ocorrência ou não de novação quando a câmara de liquidação se coloca como contraparte entre o vendedor e o comprador após o fechamento de um negócio.
} 
Alguns doutrinadores brasileiros de vulto, em especial de Direito Comercial $^{12}$, já trataram com maestria de certos aspectos importantes das caixas de liquidação e custódia, mas, no mais das vezes, enquanto mecanismos auxiliares do mercado bursátil e de futuros.

O propósito deste trabalho é ir além, elegendo as caixas de liquidação como foco principal; não como acessório de outras atividades. Isso porque as clearing houses auxiliares das bolsas de valores, que reúnem compradores e vendedores de títulos e valores mobiliários, constituem apenas uma das espécies de caixa de liquidação.

O Sistema Financeiro Nacional contempla outras câmaras de grande relevância, que reúnem agentes econômicos em torno de negócios envolvendo outros objetos, como reservas bancárias, câmbio, títulos de crédito, transferências de fundos, pagamentos com cartão de crédito, títulos públicos, entre outros.

Mas, se de um lado o estado da arte do ponto de vista econômico e tecnológico parece andar pari passu com a velocidade de desenvolvimento das caixas de liquidação e dos novos meios de pagamento, resta saber se o mundo jurídico também está em sintonia com essa realidade.

Assim, também constitui objeto deste trabalho o levantamento do panorama histórico desses temas e do arcabouço legislativo sobre a matéria no Brasil, cotejando a experiência registrada no Direito Comparado.

Seguindo essa linha, inicialmente será traçada breve contextualização histórica, legislativa e doutrinária das figuras relacionadas às caixas de liquidação no Brasil e no Direito Comparado, com especial destaque para as circunstâncias da criação das primeiras caixas de liquidação de que se tem notícia.

Depois, procurar-se-á detalhar a dinâmica e os diferentes mecanismos de funcionamento das caixas de liquidação, de forma a traduzir, na medida do possível, para o bojo de um trabalho jurídico, determinadas questões práticas da liquidação financeira que

${ }^{12}$ Com destaque para as teses de doutoramento de Marcos Paulo de Almeida Salles e Francisco Satiro de Souza Júnior. 
não são corriqueiras a um operador do Direito, com o cuidado de não se utilizar de um tecnicismo operacional exacerbado.

Ao mesmo tempo, o trabalho investigará a aderência ou não dessas rotinas de liquidação a institutos jurídicos já existentes, levantando as questões legais que normalmente não são lembradas pelos operadores do mercado financeiro. Será proposto, também, um modelo de classificação das caixas de liquidação.

Com isso, (i) será traçado o regime jurídico ao qual são submetidas, no Sistema de Pagamentos Brasileiro, as câmaras de liquidação e seus institutos correlatos que forem identificados ao longo da pesquisa; e (ii) aferir-se-á o grau de risco assumido pelo Estado, enquanto ordenador da política econômica, ao organizar o Sistema de Pagamentos Brasileiro da forma vigente e conferir poder de auto-regulação aos agentes econômicos.

Serão levantados dados referentes às caixas de liquidação no Brasil, Estados Unidos, União Européia e noutras economias relevantes, para que, com base numa análise documental indutiva e na pesquisa da bibliografia existente sobre o assunto, se possa aferir a eficácia dos sistemas de liquidação escritural, especialmente após o auge da crise financeira internacional experimentada entre 2008 e 2009.

Frise-se, novamente, que o principal objetivo desse trabalho é traçar um panorama do estado da arte das caixas de liquidação no âmbito do Sistema de Pagamentos Brasileiro. Dada a especificidade do tema e o ineditismo da sua abordagem dessa forma isolada pelo Direito no Brasil, justifica-se desde já a prevalência de material doutrinário estrangeiro em referência.

Todavia, para que este não se constitua em um estudo simplesmente descritivo, ao longo de todo o trabalho será feito esforço no sentido de se obter, concomitantemente ao panorama geral das clearings, uma abordagem analítica dos problemas identificados, por meio da análise da evolução histórica das caixas de liquidação sob os aspectos pertinentes ao tema e de material doutrinário, assim como, quando possível - e eficiente - cotejamento do Direito Comparado. 
Não só por isso, mas também pela total assimilação pelos agentes econômicos de um sem número de expressões estrangeiras, é que alguns termos que não encontram tradução direta ou lógica para o Português aparecerão neste trabalho na língua original. $\mathrm{O}$ autor, pelo seu absoluto respeito pela língua pátria, procurará traduzi-los na medida do possível. Também poderão surgir palavras utilizadas fora da sua acepção jurídica, mas que encontram sentido no mercado financeiro e de capitais.

Finalmente, quando das conclusões, após a identificação de possíveis problemas e lacunas no disciplinamento das caixas de liquidação, a dissertação contemplará possíveis sugestões para o aprimoramento do instituto no Brasil, com fundamento nas melhores práticas experimentadas e nos princípios comumente aceitos no Direito Comparado. 


\section{PANORAMA HISTÓRICO}

Já é de longa data a consolidação dos usos e práticas mercantis enquanto fontes do Direito Comercial pela doutrina. E não poderia mesmo ser diferente, uma vez que a história mostra que esse crédito dado à inventividade do empresariado é um grande incentivo à busca incessante dos empreendedores pelo progresso e pela eficiência econômica dos negócios.

Faz-se necessário, portanto, levantar o histórico que serve de "suporte fático" 13 para os elementos de interesse ao mundo jurídico que ora são colocados em estudo, tenham eles sido ou não já tutelados pelo Direito Positivo.

${ }^{13}$ Expressão cunhada por Pontes de Miranda no Tratado das Ações, Tomo I, 2.ed. São Paulo: Revista dos Tribunais, 1972, p.4. 


\subsection{Meios alternativos de pagamento}

Pode-se dizer que, após a criação da moeda, o cartão de crédito foi o primeiro meio de pagamento relevante, de alcance massificado, institucionalizado pelo mercado e que não se enquadra no rol de títulos de crédito.

É muito interessante a colocação feita por Edgard Lacerda Teixeira ${ }^{14}$ na provável primeira citação feita à figura do cartão de crédito na doutrina jurídica brasileira, numa das primeiras edições da Revista de Direito Mercantil:

"Primeiro, foi a troca - ou escambo - de mercadorias. Depois, a mercadoria moeda (gado, chá, sal, tabaco etc.). Mais tarde, os metais preciosos e, finalmente, a moeda propriamente dita é adotada como intermediária das trocas e denominador comum: de valores econômicos.

Os inconvenientes e os riscos inerentes ao transporte físico da moeda de um local para outro levaram ao aparecimento, no comércio inter-regional ou internacional, das letras de câmbio.

Surgem, então, em sua rica variedade instrumental, os títulos de crédito da era moderna. Os cheques substituem a posse física da moeda e estimulam os meios de pagamento.

Aproximamo-nos do estágio das sociedades sem papel-moeda (cashless society). Eis que agora, mercê dos cartões de crédito e dos computadores eletrônicos, já se vislumbra a dispensa do próprio cheque como instrumento de pagamento. Estaríamos nos limiares da Checkless society ${ }^{15}$ ".

Consta $^{16}$ que a idéia de se criar um cartão de crédito surgiu quando, em 1949, o empresário Frank McNamara, após jantar com clientes seus no restaurante Major's Cabin Grill de Nova York, propôs-se a pagar a conta, mas descobriu que não tinha dinheiro nem cheques, por ter esquecido sua carteira no hotel. A situação constrangedora foi

\footnotetext{
${ }^{14}$ TEIXEIRA, Egberto Lacerda. Os Cartões de Crédito Bancário. Revista de Direito Mercantil, São Paulo, $8 / 122$.

15 Tradução livre: sociedade sem cheque.

${ }^{16}$ MANDELL, Lewis. The Credit Card Industry: A History. Boston: Twayne Publishers, 1990.
} 
resolvida porque sua esposa portava alguma soma em dinheiro e terminou por pagar a conta.

Inquieto, McNamara comentou o acontecido com seu advogado Ralph Schneider e ambos tiveram a idéia de criar um clube de comensais ${ }^{17}$, que, de alguma forma, validasse a idoneidade financeira dos seus sócios perante determinados estabelecimentos conveniados ao clube, nos quais eles poderiam consumir sem que precisassem pagar com dinheiro ou cheque no ato. O pagamento seria feito posteriormente, mediante apresentação de um extrato de uso dentro de determinado período.

O clube foi fundado inicialmente com duzentos sócios amigos da dupla e vinte e sete restaurantes conveniados. A primeira transação foi realizada em 8 de fevereiro de 1950 no mesmo restaurante onde McNamara havia tido a grande idéia após seu constrangimento.

Em Los Angeles, havia iniciativa similar mantida por Alfred Bloomindale denominada Dine and Sign ${ }^{18}$. Bloomindale e os fundadores do clube de comensais se reuniram e decidiram unir esforços e ampliar o rol de estabelecimentos conveniados para hotéis, lojas e diversos outros segmentos, sendo fundado aí o The Diners Club Inc.

Apenas dois anos foram suficientes para transformar o cartão de crédito do Diners Club numa febre total no mercado norte-americano, por um lado pelo status conferido aos seus portadores e, por outro, pelo grande interesse dos estabelecimentos em se conveniarem, mirando os potenciais clientes endinheirados da época.

O monopólio do Diners Club pouco durou, pois logo na década de 1960 surgiram outros clubes do tipo, especialmente o American Express e o Carte Blanche (que posteriormente firmou parceria com o Diners).

\footnotetext{
${ }^{17}$ Tradução livre de diners' club.

${ }^{18}$ Tradução livre: jante e assine.
} 
Os bancos também se interessaram pelo negócio, criando o BankAmericard e o Interbank Mastercard, que hoje são respectivamente a Visa e a Mastercard, maiores associações de emissores de cartões do mundo.

Conforme ressaltado por Fran Martins ${ }^{19}$ e Nelson Abrão ${ }^{20}$, todavia, ao contrário do que se possa imaginar, idéias muito parecidas com essa já engatinhavam lá mesmo nos Estados Unidos desde a década de 1920, por iniciativa de redes de postos de combustível, cadeias de hotéis e grandes lojas de departamento. Eles emitiam cartões aos seus clientes mais fiéis e lhes concediam crédito ou facilidades de pagamento - sempre nas filiais ou franquias da companhia emissora.

Entre os brasileiros, também está incorporado historicamente às práticas comerciais algo semelhante - o "fiado". Especialmente nas praças e estabelecimentos de menor porte, onde alguns clientes são individualmente conhecidos pelos empresários, esse instituto secular permanece. Frise-se que também, nesse caso, o crédito conferido por um empresário restringe-se ao seu estabelecimento.

Bom, mas foi realmente o Diners Club que desenhou o cartão de crédito na sua forma atual, a uma, porque foi efetivamente criada uma empresa cujo objeto precípuo era a emissão e administração de cartões de pagamento, que não enxergava nisso apenas um negócio acessório da sua atividade principal; a duas, porque conferia uma grande liberdade aos seus sócios para utilizarem esse meio de pagamento e seu crédito numa rede bem maior e mais diversificada de estabelecimentos - aproximando-se da circulabilidade própria dos títulos de crédito.

No Brasil, os primeiros cartões de crédito foram emitidos na década de 1960, quando o empresário tcheco Hanus Tauber trouxe a franquia do Diners Club. O primeiro emissor bancário no Brasil foi o Bradesco, em 1968, mas somente nas duas décadas seguintes é que as operações com cartões deslancham, com o pesado investimento nesse negócio por outros grandes emissores, com destaque para o Banco Citibank, que criou a administradora de cartões Credicard, e outras instituições financeiras.

\footnotetext{
${ }^{19}$ MARTINS, Fran. Contratos e Obrigações Comerciais. 14.ed. Rio de Janeiro: Forense, 1999, p. 509.

${ }^{20}$ ABRÃO, Nelson. Direito Bancário. 12.ed. São Paulo: Saraiva, 2009, p. 190.
} 
Um importante passo nesse mercado foi dado em 1991, quando as administradoras de cartão de crédito brasileiras receberam a autorização para a emissão de cartões com validade internacional. Desde então, o número de cartões emitidos e o volume financeiro movimentado por meio deles têm crescido vertiginosamente, conforme demonstrado por alguns dos números já expostos.

A última grande movimentação nesse segmento aconteceu bem recentemente, em $1^{\circ}$ de julho de 2010, quando foi efetivamente aberto o mercado de credenciamento de estabelecimentos para o recebimento de cartões de crédito.

Antes de tal data, as duas maiores bandeiras de cartão no Brasil e no mundo mantinham na prática uma espécie de duopólio no ramo de adquirência ${ }^{21}$, uma vez que somente a Cielo (outrora Visanet) e a Redecard tinham autorização da Visa e da Mastercard, respectivamente, para atuar nesse segmento. Por razões de conveniência e economia, e considerando que as operações com uma das bandeiras citadas transitavam numa rede isolada, cada adquirente possuía seu próprio sistema de liquidação financeira.

Com o advento da multi-adquirência em 2010, como o mercado vem chamando o cenário após a quebra desse duopólio, não só os dois adquirentes supracitados estão autorizados a credenciar estabelecimentos comerciais para ambas as bandeiras e tantas outras (e operar com transações de todas elas), como quaisquer outros concorrentes podem entrar nesse mercado ${ }^{22}$.

Considerando o momento de forte crescimento econômico brasileiro e o conseqüente boom no uso dos meios eletrônicos de pagamento, muitos adquirentes

\footnotetext{
${ }^{21}$ Segmento de credenciamento e habilitação de estabelecimentos comerciais para o recebimento de cartões de crédito e débito como meio de pagamento. A figura do adquirente não se confunde com a do emissor, pois enquanto este detém a autorização das bandeiras para a emissão dos plásticos para os clientes finais, aqueles atuam na ponta oposta do pagamento via cartão: o EC (estabelecimento comercial). De uma forma simplificada, as bandeiras outorgam aos adquirentes o poder de credenciar EC's e administrar uma solução tecnológica de captura eletrônica das transações realizadas nesses locais e de conexão dos mesmos aos sistemas de autorização e liquidação.

22 Desde que atendidos um sem número de requisitos específicos estabelecidos em âmbito local e internacional pelas bandeiras.
} 
estrangeiros relevantes têm ensaiado sua estréia no mercado brasileiro, segundo a imprensa ${ }^{23}$.

O destaque conferido neste trabalho aos cartões de crédito justifica-se pelo fato de esses instrumentos terem sido indubitavelmente os precursores de um sem número de novidades no mercado de meios de pagamento. Até o seu surgimento, por muito tempo, os tradicionais meios - papel moeda e títulos cartulares - reinaram de forma absoluta como únicos mecanismos de pagamento.

Além disso, como os cartões de crédito já estão incorporados ao cotidiano dos cidadãos praticamente do mundo todo, eles têm servido de plataforma para facilitar o lançamento dos novos meios de pagamento que têm surgido.

Um exemplo é o pagamento contactless telefônico, pelo qual o portador precisa apenas aproximar seu aparelho celular de um dispositivo instalado no estabelecimento comercial. Ao invés de emitir um novo instrumento de pagamento autônomo, na prática o que se vê é apenas a vinculação do instrumento contactless a um cartão de crédito já mantido pelo dono do celular.

No mais das vezes, portanto, os avançados meios de pagamento que têm sido criados à profusão são apenas novos canais de uso de que o portador dispõe para acessar o crédito que lhe foi concedido pelo emissor dos já tradicionais cartões de crédito.

Essa prática é interessante pelo aspecto comercial, já que, se um novo canal de pagamento for totalmente desvinculado de um meio de pagamento consolidado e préexistente $^{24}$, um novo esforço de vendas será demandado e uma nova análise de crédito do portador deverá ser realizada, correndo o emissor o risco de não conseguir vender o novo meio de pagamento, pelo possível esgotamento do crédito concedido pelo mercado. Ao invés de conceder mais crédito, a solução mais prática e viável é aproveitar o já deferido em outro instrumento.

${ }^{23}$ Reuters Brasil. First Data será nova concorrente de Redecard e Cielo. 1/7/2010.

Valor Econômico. Mais uma estrangeira disputa filão de cartões (Global Payments). 4/1/2011.

Folha de São Paulo. Citi volta ao ramo de cartões dois anos após vender Redecard (Elavon). 29/12/2010.

${ }^{24} \mathrm{O}$ exemplo clássico é o cartão de crédito. 
Além de facilitar a comercialização, essa vinculação ${ }^{25}$ confere mais segurança e higidez às relações comerciais, uma vez que os cartões de pagamento são ferramentas devidamente incorporadas não só aos costumes comerciais e hábitos do consumidor, mas também ao sistema financeiro. Assim, quando atrelado a um cartão de crédito, qualquer novo meio de pagamento avançado se insere no sistema financeiro por meio das estruturas e fluxos já utilizados e consolidados por aquele.

Tal segurança tem importância crucial para que se mantenha um ambiente propício à criação contínua de meios de pagamento tão confiáveis quanto inovadores, como se analisará mais à frente neste trabalho.

\footnotetext{
${ }^{25}$ Amarração entre o instrumento de pagamento pré-existente e um novo canal de acesso.
} 


\subsection{Caixas de liquidação}

Exposto sucintamente o histórico dos meios alternativos de pagamento, com destaque para o cartão de crédito, passa-se ao levantamento da evolução da infra-estrutura de suporte à liquidação dos mesmos, com especial destaque às caixas de liquidação.

Em que pesem as notícias históricas dos primórdios das caixas de liquidação remontarem à idade média nas feiras de $\operatorname{Lion}^{26}$, consta que foi em Londres, em torno de 1770, que surgiu a primeira clearing de pagamentos interbancários.

Até então, os bancos londrinos haviam estabelecido um sistema de compensação manual e bastante rudimentar. Cada banco separava diariamente, por instituição emissora, os cheques que haviam sido depositados nas suas contas.

Em seguida, mandava um funcionário seu a cada um dos outros bancos para compensar tais papéis com aqueles emitidos por seus clientes e depositados nessas outras casas, registrando os saldos entre si. As diferenças eram acertadas diretamente entre os bancos, mediante pagamento em dinheiro de tempos em tempos.

Para facilitar esse processo, os prepostos dos bancos passaram a se encontrar informalmente na taverna Five Bells, no histórico corredor financeiro da Lombard Street, para trocar os cheques e outros títulos e acertar as diferenças de saldo no ato.

Com o crescimento do volume transacionado, em 1773, uma sala do Five Bells foi separada unicamente para o encontro diário de liquidação entre os bancos - por eles chamada de clearing room. Logo essa sala ficou pequena, e um imóvel vizinho foi alugado pelos bancos para sediar os encontros.

${ }^{26}$ SOUZA JÚNIOR, Francisco Satiro de. Regime jurídico das opções negociadas em bolsas de valores. 2002. 185f. Tese (Doutorado em Direito) - Programa de Pós-Graduação em Direito Comercial, Universidade de São Paulo, São Paulo, 2002. 
Esses encontros de liquidação foram acontecendo informalmente com base nas regras do direito comum, até que, em 1821, um comitê permanente foi instituído para regular esses encontros de contas entre os bancos londrinos: o Committee of London

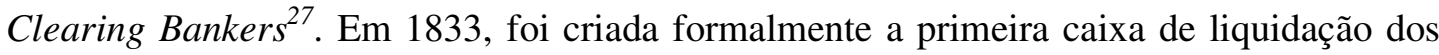
banqueiros $^{28}$, com capital integralizado inicialmente por 39 bancos, entre eles alguns existentes até hoje, como o Barclays.

Em 1854, houve um importante avanço, que foi a substituição dos pagamentos em dinheiro das diferenças resultantes das liquidações entre os bancos por ajustes entre contas mantidas pelos mesmos junto ao Banco da Inglaterra ${ }^{29}$, mediante troca de cheques emitidos por este. Essa sistemática funciona até hoje através da Cheque and Credit Clearing Company $(C C C C)^{30}$, mas sem o suporte de cheques do Banco da Inglaterra, pois os ajustes são feitos eletronicamente.

Paralelamente, nos Estados Unidos, em 1853, era criada a New York Clearing House Association ${ }^{31}$, também com o objetivo de simplificar e impor ordem ao caótico processo de liquidação entre os bancos de Nova York de então ${ }^{32}$. Ainda que por outros motivos históricos, o contexto era bem similar ao descrito na Inglaterra. Veja-se:

"In the decade before the Clearing House was founded, banking had become increasingly complex. From 1849 to 1853 - years highlighted by the California gold rush and construction of a national railroad system the number of New York Banks increased from 24 to 57. Yet settlement procedures remained unsophisticated. As had been the practice for years,

\footnotetext{
${ }^{27}$ Em tradução livre: Comitê dos Banqueiros Liquidantes de Londres.

${ }^{28}$ Bankers' Clearing House.

${ }^{29}$ CCCC. The clearings - early days. Disponível em: <http://www.chequeandcredit.co.uk/information//page/the_clearings_-_early_days/>. Acesso em 16/8/2010.

${ }^{30}$ Companhia de Liquidação de Cheques e Crédito, sociedade cujas ações são distribuídas igualmente entre seus membros desde 1895 .

${ }^{31}$ Associação da Caixa de Liquidação de Nova York.

32 The New York Clearing House Association. New York Clearing House - Historical Perspective. Disponível em: <http://www.theclearinghouse.org/docs/000591.pdf>. Acesso em 17/8/2010.
} 
banks settled their accounts by employing porters to travel from bank to bank to exchange checks for bags of coin, or 'specie'., „33

Em agosto daquele ano, um caixa de banco chamado George Lyman publicou um artigo propondo aos bancos que estabelecessem um escritório para centralizar os envios e recebimentos de cheques, pois da forma que estava havia muito espaço para abusos e erros. Ele conclamou os demais encarregados de caixa a entrarem em contato consigo, se houvesse interesse em levar a idéia adiante.

A resposta foi imediata e, após somente dois meses, era organizada oficialmente a New York Clearing House $e^{34}$ no número 14 da Wall Street, com a primeira liquidação multilateral sendo executada por cinqüenta e dois bancos. No primeiro dia, foi liquidado um volume de US\$22,6 milhões; após duas décadas, o volume diário ultrapassou US \$100 milhões e nos últimos anos têm sido liquidados uma média de US\$20 bilhões a cada dia somente nessa câmara.

Também na segunda metade do século XIX surgiram as primeiras caixas de liquidação atreladas a outros negócios que não os bancários. É o caso das clearings de produtos primários de Havre (França) e de Nova York (EUA), instaladas no ano de 1882 com o objetivo de servir de ambiente de adimplemento de negócios envolvendo café e algodão. Em 1887, em Hamburgo (Alemanha) e na Antuérpia (Bélgica), surgiram outras caixas de liquidação, para o adimplemento de negócios com café e lã.

No Brasil, o primeiro registro da espécie foi o da Caixa de Liquidação da Companhia Registradora de $\operatorname{Santos}^{35}$, em 1905, que intermediava o adimplemento de negócios envolvendo café. Como havia oscilação entre as cotações do produto no período

\footnotetext{
${ }^{33}$ Tradução livre: Na década anterior à fundação da Clearing House, o sistema bancário havia se tornado cada vez mais complexo. De 1849 a 1853 - anos marcados pela corrida do ouro da Califórnia e pela construção de uma rede nacional [EUA] de estradas de ferro - o número de bancos de Nova York aumentou de 24 para 57. Contudo os procedimentos de liquidação permaneciam ultrapassados. Como era praticado comumente há muitos anos, os bancos compensavam suas contas empregando portadores para viajar de banco a banco para trocar cheques por malas de moeda ou dinheiro em espécie (The New York Clearing House Association, op.cit.).

${ }^{34}$ Caixa de Liquidação de Nova York.

${ }^{35}$ PEREIRA FILHO, Valdir Carlos. Clearing Houses: Aspectos jurídicos relevantes e seu papel no mercado de capitais e no sistema de pagamentos brasileiro. Revista de Direito Bancário e do Mercado de Capitais, São Paulo, v. 27, p. 64-83, 2005.
} 
entre a conclusão e a execução dos contratos de venda a termo, as partes tinham dificuldade em prestar e gerenciar garantias entre si, papel que era, então, delegado para a Caixa.

Em 1913, o legislador brasileiro editou a Lei 2.841, que passou a condicionar a validade dos contratos de café a termo, entre outros requisitos, ao registro do negócio no âmbito de uma caixa de liquidação ${ }^{36}$, um marco de extrema importância para a validação do funcionamento das mesmas no Brasil.

Em 1915, foi instituída a Companhia Registradora e Caixa de Liquidação do Rio de Janeiro e, cinco anos depois, a Caixa de Liquidação da Companhia de Registro Mercantil do Rio de Janeiro, e outras tantas daí em diante conforme os negócios iam demandando.

O Decreto-Lei 1.344/1939 conferiu às bolsas a possibilidade de instituir uma câmara de compensação para, facultativamente, promover a liquidação e compensação das operações com os títulos nela negociados ${ }^{37}$. Em seguida, com o advento da Lei do Mercado de Capitais (Lei 4.728/1965), foi instituído o disciplinamento concentrado desse mercado pelo Conselho Monetário Nacional ${ }^{38}$.

Com base em tal Lei, o CMN editou, em 1966, a Resolução 39, que introduziu o primeiro Regulamento sobre as bolsas de valores e, nos arts. 94 a 99, disciplinou o funcionamento das caixas de liquidação, que agora deveriam ser organizadas

\footnotetext{
${ }^{36}$ Art. 77. Os contractos de compra e venda de mercadorias a termo só serão validos na praça do Rio de Janeiro e nas dos Estados onde funccionarem bolsas officiaes de mercadorias, quando lavrados por corretores, cujo numero será illimitado, declarados na bolsa e feito o registro nas caixas de liquidação que se organizarem, observadas as disposições legaes relativas ao typo de sociedade mercantil que adoptarem.

Art. 78. Os Estados poderão crear e organizar as camaras de corretores e as bolsas de mercadorias ou bolsas especiaes para certa e determinada mercadoria.

Art. 79. Para garantia da effectividade da liquidação dos contractos a termo deverão as partes fazer, de accôrdo com as tabellas préviamente organizadas, um deposito inicial e posteriormente reforçal-o, sempre que haja modificação na cotação das mercadorias vendidas.

Art. 80. As caixas de liquidação poderão reter os depositos iniciaes e as margens para garantia das operações de que se incumbirem, bem como exigir reforço, quando as coberturas parecerem insufficientes.

37 Art. $9^{\circ}$ Cada bolsa de valores poderá instituir uma câmara de compensação para promover, facultativamente, a liquidação e compensação de operações de títulos.

${ }^{38}$ Art. $1^{\circ}$ Os mercados financeiro e de capitais serão disciplinados pelo Conselho Monetário Nacional e fiscalizados pelo Banco Central da República do Brasil.
} 
na forma de sociedades anônimas controladas pelas bolsas, estas detendo pelo menos 2/3 do seu capital votante e o poder de nomear seu Superintendente-Geral ${ }^{39}$.

\section{Com a Lei 6.385/1976, a Comissão de Valores Mobiliários - CVM passou a} fiscalizar e regulamentar também as câmaras de liquidação.

Daí em diante, outras Resoluções ${ }^{40}$ do CMN foram editadas, de forma a regular a organização, o funcionamento $\mathrm{e}$ as responsabilidades das clearings, estabelecendo finalmente que as câmaras de liquidação não poderiam mais ser um setor das bolsas de valores, nem se misturar com o ambiente destas.

Elas deveriam se constituir como sociedades anônimas com a finalidade exclusiva de liquidar as obrigações dos participantes de determinado mercado ao qual nasceram vinculadas.

Com o advento das Leis 10.214/2001, que instituiu o Sistema de Pagamentos Brasileiro, e da 10.303/2001, que alterou o disciplinamento das sociedades

\footnotetext{
39 Art. 94. As Caixas de Liquidação constituir-se-ão sob a forma de sociedades anônimas, com capital subscrito de no mínimo Cr\$50.000.000 (cinqüenta milhões de cruzeiros), integralizado em moeda corrente e representado por ações nominativas.

Art. 95. As Bolsas de Valores deterão pelo menos 66\% (sessenta e seis por cento) do capital social votante das respectivas Caixas de Liquidação, cabendo a cada um dos associados da Bolsa subscrever e integralizar uma ação.

Art. 96. As Caixas de Liquidação serão dirigidas por pessoas de comprovada idoneidade técnica e moral e pelo Superintendente Geral da Bolsa de Valores, que as presidirá.

Parágrafo único. O funcionamento das Caixas de Liquidação dependerá de autorização do Banco Central e ficará sujeito à sua permanente fiscalização.

Art. 97. A autorização de que trata o artigo anterior será dada por prazo indeterminado e poderá ser cancelada a qualquer momento, sempre que apuradas irregularidades em seu funcionamento.

Art. 98. Dependerão, também, de aprovação pelo Banco Central o estatuto social e o regulamento de operações das Caixas de Liquidação.

Art. 99. As Caixas de Liquidação poderão realizar as seguintes operações:

I - registrar, liquidar e compensar operações à vista e privativamente as a termo, de responsabilidade das firmas e sociedades corretoras ou de seus comitentes;

II - receber depósitos e margens para garantia de operações realizadas por associados da Bolsa e por cuja liquidação se responsabilizem;

III - emitir certificados visando o resgate, desdobramento, conversão e transferencia de títulos negociados ou a serem negociados pelas firmas ou sociedades corretoras;

IV - descontar recibos referentes a títulos depositados e praticar as demais operações acessórias que visem a boa circulação e liquidação dos títulos e valores mobiliários negociados;

V - outras operações ou serviços de interesse das Bolsas, das firmas ou sociedades corretoras, ou da própria Caixa de Liquidação;

VI - conceder crédito operacional aos Membros das Bolsas de Valores.

${ }^{40}$ Res. CMN 922/1984, Res. CMN 1.656/1989 e Res. CMN 2.690/2000.
} 
anônimas e do mercado de valores mobiliários, as caixas de liquidação foram inseridas de forma definitiva no sistema de distribuição de títulos e valores mobiliários e tiveram reconhecido seu status de entidades auto-reguladoras. 


\section{CONCEITUAÇÃO E ENQUADRAMENTO DO TEMA}

Como é cediço, o mercado de capitais é uma das fontes mais importantes de financiamento do empresariado ${ }^{41}$ - em especial o de maior porte -, na medida em que oferece condições econômicas bem mais interessantes do que as tradicionais fornecedoras de crédito - as instituições financeiras.

Enquanto os bancos normalmente cobram taxas de juros mais elevadas por uma série de razões, no mercado de capitais o empreendedor pode levantar recursos com um custo bem inferior e em volume superior ao normalmente suportado pelo sistema bancário.

O primeiro grande motivo desse menor custo de financiamento é exatamente a inexistência de agentes intermediadores ${ }^{42}$ entre o financiador e o financiado. Como cada banco intermediador concede crédito para diversos agentes econômicos e tem por fonte de recursos outros tantos, não existe uma segregação de qual investidor está financiando qual devedor. Assim, os riscos suportados pelo intermediador nas suas operações são distribuídos entre todos aqueles que dele demandarem crédito, o que torna esse recurso mais caro ${ }^{43}$.

Em contraposição, tome-se a mais simples operação de financiamento através do mercado de capitais: determinada empresa realiza uma oferta primária de ações suas na bolsa de valores.

Os recursos oriundos da venda dos papéis entrarão no caixa da empresa sem que nenhum intermediário tenha sido envolvido, à exceção de determinados agentes que

${ }^{41}$ Cf. SCHUMPETER, Joseph A. Teoria do desenvolvimento econômico. Uma investigação sobre lucros, capital, crédito, juro e o ciclo econômico. Trad. Maria Silvia Possas. Os Economistas. Nova Cultural: 1997.

42 Assim entendidos os bancos com carteira de crédito, que têm por finalidade principal captar recursos financeiros de agentes econômicos poupadores e remunerá-los, e com isso conceder financiamento a outros agentes que demandem recursos, destes cobrando remuneração.

${ }^{43}$ Os bons pagadores terminam por cobrir os prejuízos causados pelos maus pagadores. 
apenas operacionalizam a captação ${ }^{44}$. A efetiva captação é feita pelo próprio financiado ${ }^{45}$. Trata-se, portanto, de um mercado "desintermediado", além de não sofrer grande interferência estatal.

Se a inexistência de um intermediário ${ }^{46}$ barateia consideravelmente a capitalização das empresas, por outro lado, isso poderia gerar uma insegurança entre os investidores que fornecerão os recursos para o financiamento.

Afinal, não haverá um sistema bancário garantindo a devolução dos recursos aplicados pelo poupador. Para gerar atratividade aos investidores, seria preciso desenvolver outros institutos e mecanismos que conferissem não só eficiência, mas também proteção, segurança, garantias, transparência e "elevados padrões éticos"47 aos negócios não intermediados.

É evidente que aqui não está se falando de garantia de retorno do investimento nem de níveis mínimos de rentabilidade, mas de certeza de adimplemento das obrigações entabuladas. Noutras palavras, de confiança de que o dinheiro investido será entregue ao emissor e, em algum momento futuro, o título representativo do investimento poderá ser resgatado ou, no caso do mercado secundário de ações, vendido.

Assim, um grande incentivo ao investimento em bolsas de valores é a garantia da liquidação das operações financeiras, ou seja, de que, após determinada compra e venda de um título no mercado de capitais, o vendedor receberá o dinheiro e o comprador obterá a titularidade do papel adquirido ${ }^{48}$.

\footnotetext{
${ }^{44}$ Eles apenas organizam a emissão dos papéis, cobrando pela prestação de serviços, não pelo custo do dinheiro, como o fazem os intermediários financeiros (bancos com carteira de crédito). Aqueles intermediários são apenas operacionais, não fontes de capital como estes.

45 Algumas instituições financeiras também prestam serviços operacionais na captação no mercado financeiro, mas sem misturar com sua atividade de intermediação financeira.

${ }^{46}$ Figura do underwriter, instituição responsável pela organização do lançamento e distribuição de valores mobiliários no mercado de capitais.

${ }^{47}$ PEREIRA FILHO, op. cit.

${ }^{48}$ Ou título representativo, que pode ser eletrônico e virtual.
} 
O desenvolvimento e a sustentação do mercado de capitais dependem da credibilidade do funcionamento desse sistema. Nesse cenário foi que ao longo do tempo o mercado financeiro criou e vem aprimorando continuamente as caixas de liquidação.

$\mathrm{Na}$ atualidade, de uma forma genérica, é clearing:

"a department of an exchange or a separate legal entity that provides a range of services related to the clearance and settlement of trades on the exchange and the management of risks associated with the resulting contracts. A clearing house is often central counterparty to all trades on the exchange, i.e. the buyer to every seller and the seller to every buyer",49

Ou ainda, segundo a legislação estadunidense:

"any person who acts as an intermediary in making payments or deliveries or both in connection with transactions in securities or who provides facilities for comparison of data respecting the terms of settlement of securities transactions, to reduce the number of settlements of securities transactions, or for the allocation of securities settlement responsibilities. Such term also means any person, such as a securities depository, who (i) acts as a custodian of securities in connection with a system for the central handling of securities whereby all securities of a particular class or series of any issuer deposited within the system are treated as fungible and may be transferred, loaned or pledged by bookkeeping entry without physical delivery of securities certificates, or (ii) otherwise permits or facilitates the settlement of securities transactions or the hypothecation or lending of securities without physical delivery of securities certificates.

\footnotetext{
49 Tradução livre: um departamento de uma entidade de negociação ou de uma entidade legal separada que oferece uma gama de serviços relacionados à compensação e liquidação de operações financeiras e gerenciamento de riscos associados aos contratos decorrentes. A caixa de liquidação é geralmente a intermediária de todas as negociações, ou seja, a compradora de todo vendedor e a vendedora de todo comprador (RUSSO, Daniela; HART, Terry L.; SCHÖNENBERGER, Andreas. The evolution of clearing and central counterparty services for exchange-traded derivatives in the United States and Europe: A comparison. European Central Bank - Occasional Paper Series, n.5, 2002).

${ }^{50}$ Tradução livre: [clearing é] qualquer pessoa que atue como intermediário na realização de pagamentos ou entregas ou ambos relativamente a transações com valores mobiliários ou que ofereça condições para a comparação de dados a respeito dos termos de liquidação de transações com valores mobiliários, ou para a
} 
No mercado bursátil brasileiro, o panorama é muito semelhante, devendo as câmaras de liquidação realizar:

“(i) a liquidação financeira das operações, referente ao pagamento dos valores monetários devidos em razão da transação bursátil realizada; (ii) a liquidação física, quando for o caso, caracterizada pela entrega efetiva dos ativos negociados (iii) o gerenciamento dos níveis de garantias das operações realizadas". 51

Nota-se que as definições apresentadas estão cingidas ao mundo das caixas de liquidação atreladas ao ambiente de negociação bursátil e de balcão.

Para os fins deste trabalho, todavia, o conceito é mais abrangente: são consideradas clearings as sociedades ${ }^{52}$ constituídas com a finalidade de prestar serviços relacionados à liquidação de obrigações contrapostas entabuladas entre determinados sujeitos que dela participarem, colocando-se como a pagadora de cada recebedor e a recebedora de cada pagador, ou seja, contraparte de todos os participantes.

Essa lógica de funcionamento é adotada mundo afora, como definido claramente pela IOSCO e pelo BIS $^{53}$ :

“Central Counterparties (CCPS) occupy an important place in securities settlement systems (SSSs). A CCP interposes itself between counterparties to

determinação das responsabilidades referentes à liquidação de valores mobiliários. $\mathrm{O}$ termo [clearing] também abrange qualquer pessoa, tal qual um depositário de valores mobiliários, que (i) atue como custodiante de valores mobiliários ligado a um sistema central de gestão destes instrumentos, no qual todos os títulos de uma classe específica ou séries pertencentes a qualquer emitente depositadas no sistema sejam tratadas como fungíveis e possam ser transferidas, emprestadas ou prometidoa por escrituração sem entrega física de certificados de título, ou (ii) permita ou facilite a liquidação de transações de valores mobiliários ou de consignação ou de empréstimo de valores mobiliários sem entrega física de certificados (United States Code. Securities Exchange Act. $78 c(23)(A))$.

${ }^{51}$ SOUZA JÚNIOR, op. cit., p.116.

${ }^{52}$ Ou departamentos ou sistemas.

53 BIS; IOSCO. Recommendations for Central Counterparties. Committee on Payment and Settlement Systems. Novembro/2004. 
financial transactions, becoming the buyer to the seller and the seller to the buyer. A well designed CCP with appropriate risk management arrangements reduces the risks faced by SSS participants and contributes to the goal of financial stability. CCPs have long been used by derivatives exchanges and a few securities exchanges. In recent years, they have been introduced into many more securities markets, including cash markets and over-the-counter markets. " 54

As caixas de liquidação mais conhecidas e comentadas são aquelas que operam com os negócios fechados em bolsas de valores, mas, em princípio, qualquer bem ou direito pode ser objeto de liquidação de uma clearing. O Sistema de Pagamentos Brasileiro contempla, por exemplo, uma série de caixas de liquidação segmentadas por objeto negociado, como será analisado mais à frente.

Em tese, qualquer entidade pode ter por objeto a liquidação de obrigações entabuladas entre indivíduos a ela associados. Todavia, o legislador e o regulador têm autonomia para indicar quais caixas de liquidação são sistematicamente importantes, conferindo-lhes um status diferenciado.

\footnotetext{
${ }^{54}$ Tradução livre: os intermediários de mercado ocupam um importante lugar no sistema de liquidação de valores mobiliários. O intermediário coloca-se entre as contrapartes de transações financeiras, tornando-se o comprador para o vendedor e o vendedor em relação ao comprador. Um intermediário bem estruturado com o desenho apropriado de gestão de riscos diminui os riscos a que estão sujeitos os participantes do sistema de liquidação de valores mobiliários e contribui para se alcançar o objetivo de estabilidade financeira. Os intermediários têm sido muito utilizados para negociação de derivativos e algumas negociações de valores mobiliários. Recentemente, eles vêm sendo introduzidos em mais mercados de valores mobiliários, incluindo mercados de câmbio e mercados de balcão.
} 


\section{A DINÂMICA DE FUNCIONAMENTO E AS FUNÇÕES DAS CAIXAS DE LIQUIDAÇÃO}

\subsection{A dinâmica de funcionamento das caixas de liquidação}

No Brasil, cada caixa de liquidação tem suas regras próprias de acesso e de funcionamento, obedecidas as premissas gerais estabelecidas pelo legislador e pelas entidades reguladoras.

Por definição, cada setor do mercado financeiro e de capitais possui suas caixas de liquidação cujos regramentos se alinham às especificidades demandadas pelos agentes de tal segmento.

Assim, por exemplo, os negócios com títulos públicos emitidos pelo Tesouro Nacional são liquidados no âmbito do SELIC ${ }^{55}$ com base nas suas regras próprias ${ }^{56}$. Por outro lado, as transferências de fundos entre instituições financeiras ocorrem no âmbito do $\mathrm{STR}^{57}$, obedecendo às normas específicas dessa câmara ${ }^{58}$.

A participação dos agentes econômicos nas caixas de liquidação é voluntária ou decorrente de norma. Por força da Lei 4.595/1964, por exemplo, todas as instituições financeiras devem manter suas disponibilidades de reserva no Banco Central do Brasil, e as transferências para outros bancos devem ser feitas exclusivamente por meio do STR.

A participação dos bancos no STR é, portanto, obrigatória e constitui típico exemplo de adesão compulsória, constituindo condição sine qua non à autorização para as

\footnotetext{
${ }^{55}$ Sistema Especial de Liquidação e Custódia.

${ }^{56}$ Circular BaCen 3.511/2010.

${ }^{57}$ Sistema de Transferência de Reservas.

${ }^{58}$ Circular BaCen 3.438/2010 e Carta-Circular 3.452/2010.
} 
instituições financeiras funcionarem com carteira comercial ${ }^{59}$ pelo BaCen. Pela atual sistemática não haverá banco sem reservas bancárias.

Entre as regras específicas de cada caixa de liquidação, figura entre as de maior importância o estabelecimento dos limites operacionais de cada agente, com base nas garantias aportadas por cada um deles geralmente antes do início da sua operação.

Trata-se do valor máximo ao qual cada participante pode se expor ${ }^{60}$ nas suas negociações no âmbito de determinada câmara, quando a liquidação for diferida, e não com base em saldo disponível em tempo real, como será explicado adiante. Cabe à clearing monitorar continuamente o uso do limite operacional de cada agente e garantir que o mesmo não seja excedido.

Com efeito, cada participante da caixa de liquidação poderá operar com segurança, sabendo que os negócios firmados por cada um dos outros conta com o devido lastro aportado junto à clearing, para o caso de eventual inadimplemento.

Quanto à estrutura básica dos negócios firmados no âmbito das clearings, esta se coloca como compradora de todos os vendedores e a vendedora de todos os compradores.

Ela figura como contraparte de cada um dos agentes envolvidos, e para todos os efeitos, de forma a não existir mais nenhuma relação direta entre os contratantes. Os riscos de inadimplemento, ao invés de serem suportados pelos participantes, passam a ser concentrados na figura da caixa de liquidação ${ }^{61}$.

\footnotetext{
${ }^{59}$ Circular BaCen 3.438/2010: Art. 4 A conta Reservas Bancárias é de titularidade:

I - obrigatória, para os bancos comerciais, os bancos múltiplos com carteira comercial e para as caixas econômicas; e

II - facultativa, para os bancos de investimento, os bancos de câmbio, os bancos múltiplos sem carteira comercial e os bancos de desenvolvimento.

Parágrafo único. Admite-se somente uma conta Reservas Bancárias por instituição.

60 Assim entendido o volume de negócios que o participante pode entabular, calculado com base nas garantias por ele aportadas junto à caixa de liquidação.

${ }^{61}$ Claro que mediante lastro nas garantias aportadas individualmente pelos participantes.
} 
A conseqüência imediata é que a caixa transforma cada negócio firmado no seu ambiente em dois negócios equivalentes e contrapostos de soma zero. Exemplo: a venda de um título de propriedade do participante $A$ para o $B$ liquidada na clearing $C$ se transforma em dois negócios de compra e venda, quais sejam, $A$ entrega título para $C$ e dela receberá o dinheiro e $B$ entrega o dinheiro para $C$ e dela receberá o título.

Cabe à caixa, pois, administrar a liquidação física (ativos negociados) e financeira (entrega com pagamento) da operação.

Eis o esquema das operações das Caixas de Liquidação em ambiente de bolsa:

- Momento 1 (M1)

A lança seu interesse de compra no sistema de negociação

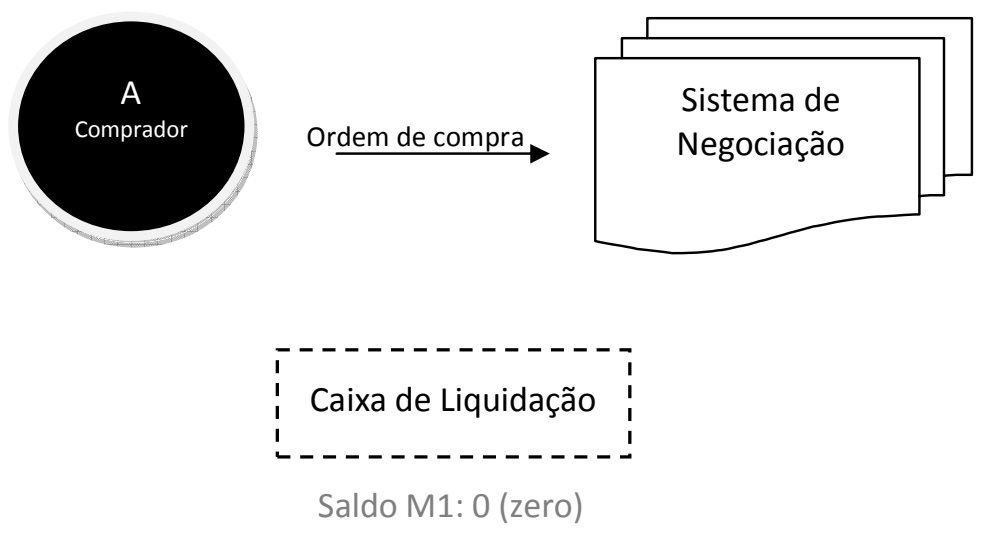

- Momento 2 (M2)

Sistema de negociação identifica ordem de venda de B

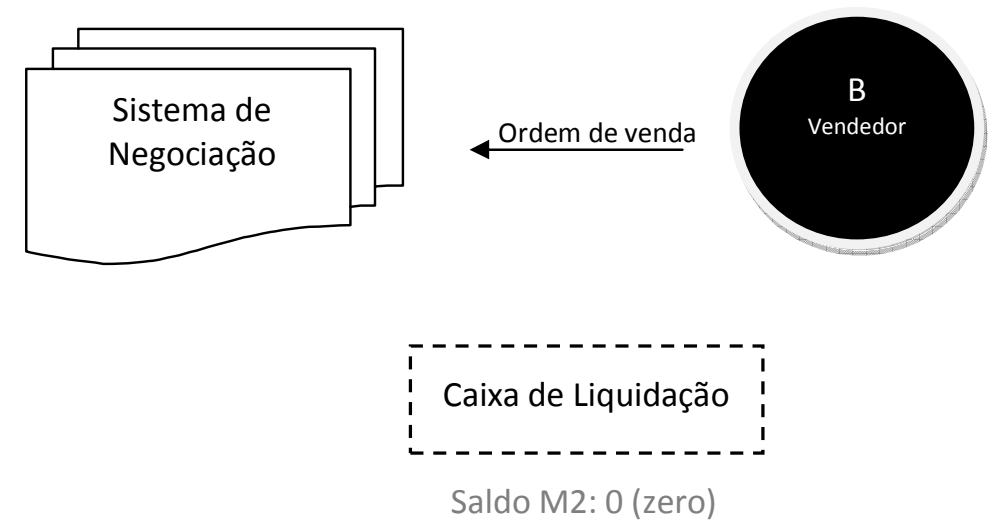


- Momento 3 (M3)

Cruzamento das ordens ${ }^{62}$ de todos os que querem negociar na Bolsa

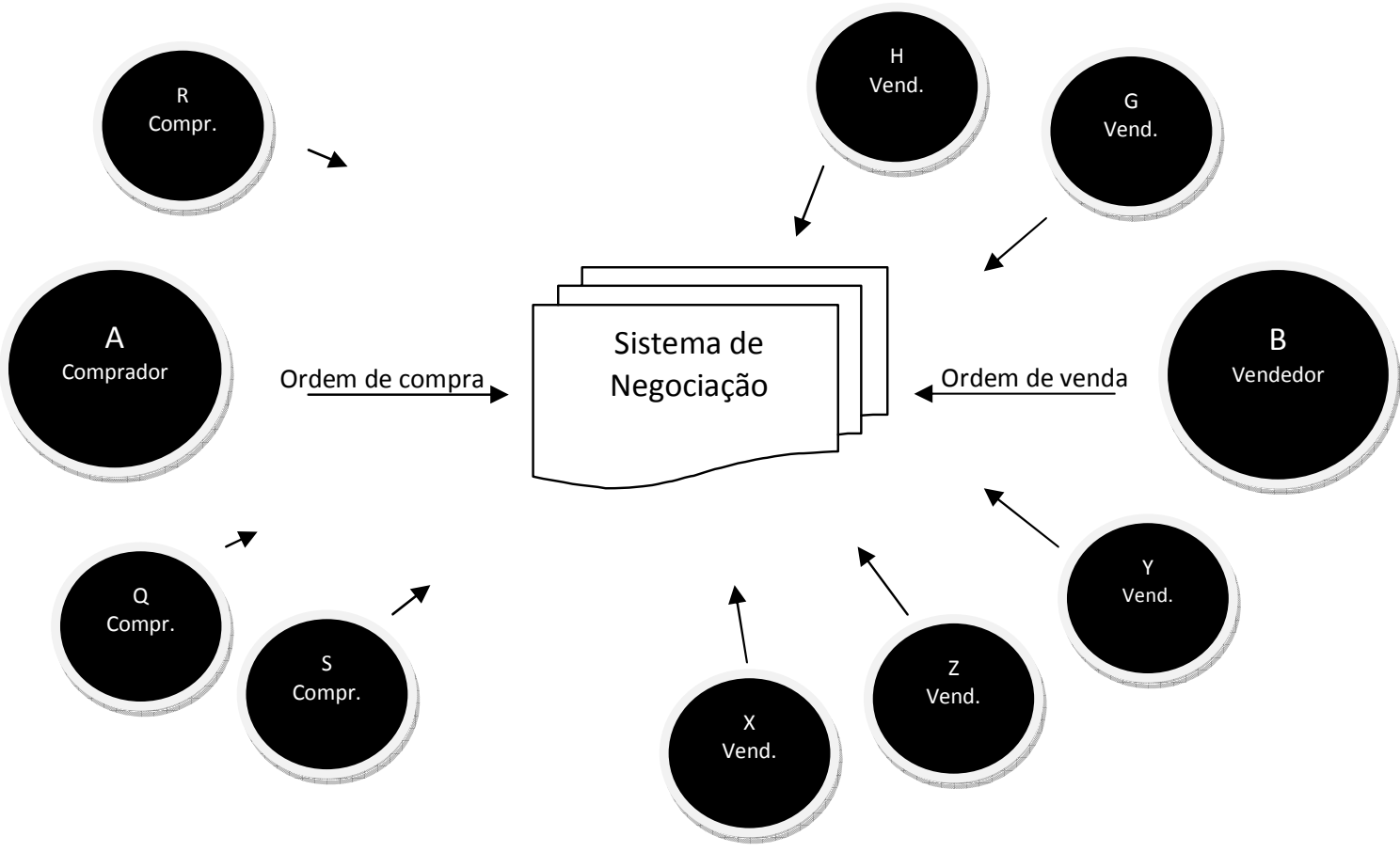

- Momento 4 (M4)

Sistema de negociação cruza as ordens equivalentes e registra a operação, automaticamente transferida para o âmbito da caixa de liquidação, que fechará e liquidará o negócio
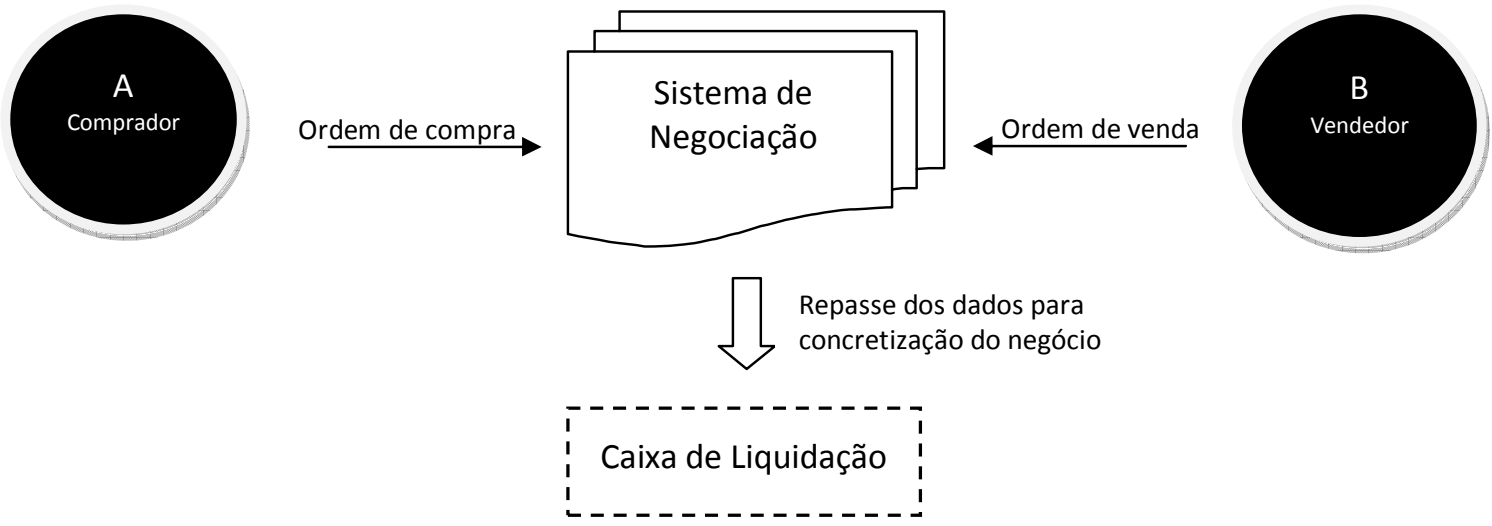

Saldo M4: 0 (zero)

\footnotetext{
${ }^{62}$ Neste momento ainda não se tem propostas de negócios, mas apenas manifestações sem destinatário dos interesses de compra e venda de ativos (a ser detalhadamente discutido adiante neste estudo).
} 
- Momento 5 (M5)

Fechamento e liquidação do negócio

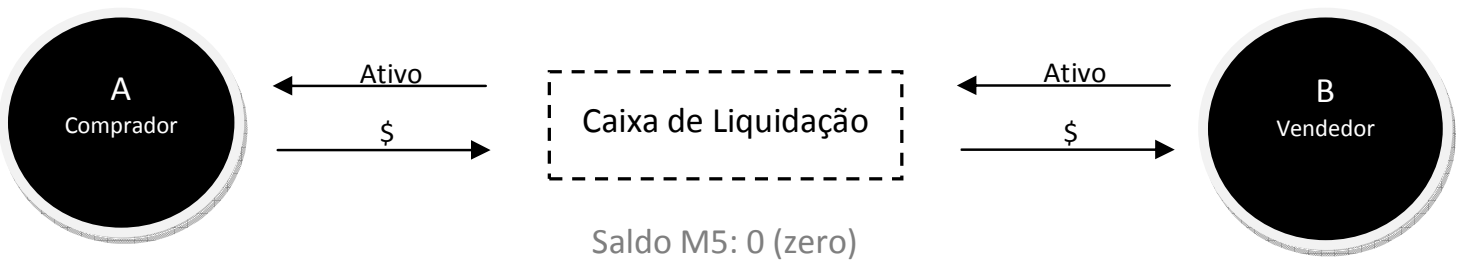

A princípio, o objetivo precípuo das caixas de liquidação não é o de lucrar com sua atividade, mas conferir higidez a determinado sistema, garantindo confiabilidade aos envolvidos e a certeza do adimplemento dos negócios fechados; até porque, como já dito, são de soma zero as obrigações contrapostas liquidadas nas clearings.

Importante registrar que até mesmo o fisco, cuja ânsia arrecadadora não é muito afeita a imunidades e isenções, isentava de $\mathrm{CPMF}^{63}$ as transações realizadas nas caixas de liquidação ${ }^{64}$, quando tal tributo incidia sobre as movimentações financeiras de toda ordem.

Em tese, a se considerar a gênese e os objetivos iniciais das clearings, não haveria lucros nem prejuízos a serem suportados pela caixa de liquidação por conta das operações em si, só lhe sendo devidos determinados emolumentos para cobrir seus custos operacionais. Tanto é que inicialmente elas eram organizadas como entidades sem fins lucrativos ou meros departamentos de outras entidades.

${ }^{63}$ Contribuição Provisória sobre Movimentação ou Transmissão de Valores e de Créditos e Direitos de Natureza Financeira, tributo arrecadado pelo Governo Federal entre 1997 e 2007 que incidia praticamente sobre todas as modalidades de movimentações financeiras.

${ }^{64}$ Lei 9.311/1996: Art. $8^{\circ}$ A alíquota fica reduzida a zero: (...) III - nos lançamentos em contas correntes de (...) dos serviços de liquidação, compensação e custódia vinculados às bolsas de valores, de mercadorias e de futuros (...). 
Mas tem se observado nestes últimos anos um fenômeno interessante, seguindo a tendência de desmutualização ${ }^{65}$ das bolsas de valores: as caixas de liquidação estão sendo geridas com o objetivo de lucro, com a aplicação de conceitos próprios de administração profissional.

Se antes, quando "filantrópicas", o único fim a ser perseguido pelas caixas de liquidação acima de tudo era aquele um tanto quanto romântico de apenas liquidar com segurança os negócios entabulados no ambiente bursátil a que dava suporte, hoje elas são vistas como negócios altamente rentáveis, se bem administrados.

Inclusive grandes fusões e aquisições de clearings têm sido observadas ${ }^{66}$, na incessante busca por maior volume e conseqüente incremento na eficiência operacional com menores custos.

A própria estrutura societária adotada por força normativa pelas caixas de liquidação, que é a de sociedade anônima, propicia as condições para a exploração lucrativa da sua atividade.

Fossem elas ainda organizadas como fundações, associações ou organizações da sociedade civil de interesse público, isso seria - como de fato era -, dificultado, pois nessas estruturas o resultado operacional positivo é, via de regra, revertido em prol da própria organização, não dos seus membros.

A organização das caixas de liquidação na forma de companhia traz consigo, inclusive, uma característica relevante para a sua função dentro do Sistema de Pagamentos Brasileiro: elas passariam a se sujeitar à legislação falimentar, ou seja, agora as clearings seriam quebráveis, como as demais sociedades anônimas. Essa possibilidade ou não - será analisada mais à frente.

\footnotetext{
${ }^{65}$ Tendência mundial de abertura do capital das bolsas de valores e reorganização na forma de companhias, antes estruturadas como associações civis sem fins lucrativos.

66 Em 2010, por exemplo, a CETIP adquiriu a GRV Solutions, empresa brasileira responsável pelo processamento e custódia das informações de transações de financiamento de veículos.
} 


\subsection{As funções das caixas de liquidação}

\subsubsection{Liquidação}

Como já vem sendo demonstrado ao longo do presente trabalho, a função primordial exercida pelas clearings é a liquidação dos negócios que são firmados no seu sistema ou em ambiente organizado do qual são auxiliares.

Toma-se, por princípio, que toda operação financeira possui três fases distintas, conforme ressalta FIGUEIREDO ${ }^{67}$ : a contratação (pagador assume compromisso de transferir fundos ao recebedor), a instrução (definição do instrumento de pagamento e início dos processos para a transferência dos fundos) e liquidação (quando os fundos estão definitivamente disponíveis ao recebedor), mediante checagem ou ajuste de contas.

A grande razão para os agentes econômicos delegarem, no mercado financeiro e de capitais, a liquidação das suas operações a uma terceira parte decorre dos riscos que seriam inerentes ao acerto individual e direto mediante troca de papel moeda.

Tais riscos e inconvenientes já eram registrados em 1831 por Albert Gallatin, então Secretário do Tesouro e Presidente do National Bank of New York ${ }^{68}$, para quem $^{69}$ a falta de um ajuste multilateral entre os diferentes agentes econômicos "produces relaxations, favors improper expansions and is attended with serious inconveniences",70, contemporaneamente exemplificado a seguir ${ }^{71}$ :

"They [the porters] accounted to each other for what had been done during the day. Thomas had left a bag of specie at John's bank to settle a balance,

\footnotetext{
${ }^{67}$ FIGUEIREDO, Rafael Paganotti; ARTES, Rinaldo. A evolução do sistema de pagamentos brasileiro e o desaparecimento do cheque: realidade ou exagero? INSPER Working Paper 136/2008. Disponível em: < http://www.insper.edu.br/sites/default/files/2008_wpe136.pdf>. Acesso em 12/12/2010.

${ }^{68}$ Banco Nacional de Nova York.

${ }^{69}$ No caso, os bancos.

${ }^{70}$ Em tradução livre: [a falta de um ajuste multilateral] gera um afrouxamento, favorece crescimentos indevidos e é acompanhada de sérios inconvenientes.

${ }^{71}$ The New York Clearing House Association, op.cit.
} 
which was due from William's bank to Robert's; but Robert's bank owed twice as much as John's. What had become of that!...It is entirely safe to say that the Presidents and Cashiers of the banks could not have untangled this medley. ",72

Ora, se esse tipo de dificuldade e de risco já existia numa remota época em que todos os encarregados de caixa se conheciam pessoalmente e mantinham entre si confiança mútua, que dirá nos dias atuais, em que é impossível saber até mesmo a lista de metade dos bancos em funcionamento ${ }^{73}$ ? Sem falar no sem número de outros agentes econômicos que participam ativamente do mercado financeiro e de capitais ${ }^{74}$.

Difícil nos dias de hoje conceber uma lógica diferente da compensação multilateral centralizada na figura das caixas de liquidação.

Imagine-se um negócio jurídico qualquer de compra e venda firmado diretamente entre duas partes e que envolva uma obrigação de pagar. Sem a interveniência de terceiros, o vendedor assume para si o risco do não pagamento por parte do comprador, enquanto este assume o risco de não entrega do bem por aquele.

Em se concretizando o inadimplemento, no Brasil, estaria à disposição do vendedor, por exemplo, a possibilidade buscar os mecanismos legais de adjudicação compulsória ou execução forçada, que, no mais das vezes, se mostram extremamente ineficientes. Seriam anos de discussão sobre o mérito e de execução forçada da obrigação no âmbito do Poder Judiciário.

\footnotetext{
${ }^{72}$ Em livre tradução: eles [os portadores] descreviam aos demais o que haviam feito durante o dia. Thomas havia deixado um saco com dinheiro em espécie no banco de John para compensar um saldo, que era devido pelo banco de William para o de Robert; mas o banco de Robert devia o dobro do devido pelo banco de John. Veja só essa situação!... Fica muito fácil dizer que os Presidentes e os encarregados de caixa dos bancos não teriam como desembaraçar esse emaranhado.

73 Apenas para fins ilustrativos, segundo o BaCen, havia em torno de 180 instituições financeiras em funcionamento no Brasil em novembro de 2010, com 20.000 agências bancárias, mais algumas dezenas de milhares de correspondentes bancários. Fonte: Quantitativo de instituições por segmento (base novembro/2010). Disponível em: <http://www.bcb.gov.br/?QEVSFN201011>. Acesso em 20/12/2010.

74 Em torno de 2.300 entidades fiscalizadas pelo Banco Central (novembro/2010). Disponível em: <http://www.bcb.gov.br/?QEVSFN201011>. Acesso em 20/12/2010.
} 
Trata-se de um modelo incompatível com o dinamismo próprio dos mercados financeiro e de capitais, nos quais um mesmo bem pode ser objeto de um sem número de transações de compra e venda entre partes diversas em questão de minutos, gerando uma cadeia ilimitada de obrigações contrapostas tendo um só ativo como substrato.

Não há como imaginar um mercado de capitais saudável e dinâmico convivendo com a possibilidade de quebra na cadeia dominial desse ativo ora considerado. Se não houvesse a certeza plena do adimplemento de cada uma das obrigações geradas em cadeia, seria impossível confiar no sistema.

A se depender de procedimentos judiciais de execução forçada do pagamento não realizado pela compra de um ativo no mercado financeiro, toda a certeza e a agilidade próprias da sistemática do mercado financeiro e de capitais seriam feridas de morte.

É nesse contexto que se insere a atividade precípua exercida pelas caixas de liquidação. Os agentes econômicos ${ }^{75}$ transferem o del credere para as caixas de liquidação, tornando estas diretamente responsáveis pelo adimplemento das obrigações deles e também de seus créditos.

Por óbvio, para que um negócio seja assegurado por uma clearing, o mesmo deverá ser firmado no ambiente dela, ou seja, local $^{76}$ onde as variáveis são por ela monitoradas continuamente.

Para viabilizar este controle das clearings, compradores e vendedores, reunidos virtual ou fisicamente no mesmo ambiente de negociação, não interagem diretamente desde o momento da proposta até a aceitação e liquidação das suas mútuas obrigações. As caixas de liquidação é que se colocam como contrapartes diretas.

\footnotetext{
75 Diretamente ou, na maioria das vezes, através de sociedades corretoras, mediante contrato de comissão, quando no âmbito das bolsas de valores.

${ }^{76}$ Físico ou virtual.
} 
Nesse cenário, esta relação pode ser entendida como decorrente de estipulação em favor de terceiros, regulada no Brasil fundamentalmente pelos arts. 436 a $438^{77}, \mathrm{CC}$, conforme inclusive defendido por SALLES ${ }^{78}$, que entende que cabe

“a eles [agentes de liquidação e compensação de negócios a termo] exigir das partes contratantes o cumprimento das obrigações, assegurando-se por meio das avaliações de crédito e garantia que entender suficientes para o fiel cumprimento desta posição [de estipulante] no negócio jurídico”.

Interessante ressaltar que dentre as diferentes teorias sobre a natureza jurídica da estipulação em favor de terceiros $^{79}$, uma vem a calhar ao sistema de funcionamento das caixas de liquidação: a da obrigação unilateral.

Segundo BAUDRY-LACANTINERIE ${ }^{80}$, a pactum in favore tertii seria uma declaração unilateral de vontade, mediante a qual o terceiro beneficiário torna-se credor na medida em que seu direito se sustenta com essa declaração unilateral do promitente.

Ora, no caso das caixas de liquidação de ambientes negociais, já que sua atuação só se inicia quando há o encontro de duas ordens opostas e equivalentes, o que se pode concluir é que são materializadas em cada negócio duas estipulações em favor de terceiros, com as mesmas partes em posições distintas, mesmo objeto e obrigações convergentes $^{81}$.

\footnotetext{
${ }^{77}$ Lei $10.406 / 2002$ :

Art. 436. O que estipula em favor de terceiro pode exigir o cumprimento da obrigação.

Art. 437. Se ao terceiro, em favor de quem se fez o contrato, se deixar o direito de reclamar-lhe a execução, não poderá o estipulante exonerar o devedor.

Art. 438. O estipulante pode reservar-se o direito de substituir o terceiro designado no contrato, independentemente da sua anuência e da do outro contratante.

Parágrafo único. A substituição pode ser feita por ato entre vivos ou por disposição de última vontade.

${ }^{78}$ Op. cit., p.65.

79 Teoria da oferta, da gestão de negócios, da obrigação unilateral e da natureza sui generis (cf. FIUZA, Cesar. Direito Civil: curso completo.

${ }^{80}$ Apud LOPES, Miguel Maria de Serpa. Curso de Direito Civil. v.3. 5.ed. São Paulo: Freitas Bastos, 1989.

${ }^{81}$ Simultaneamente a clearing estipula em nome de $A$ em favor de $B$ e de $B$ em favor de $A$.
} 
Aliás, em se tratando do mercado bursátil, com o avanço tecnológico da automatização dos ambientes negociais no mercado financeiro e de capitais, e com o fim do pregão viva voz, as partes não mais se encontram, pelo menos fisicamente, para negociar as condições do contrato. Só lhes restaria o contato virtual, que também foi praticamente extinto pela atuação das caixas de liquidação.

Na dinâmica atual dos fechamentos de negócios nas bolsas de valores, o que ocorre é o lançamento eletrônico, de um lado, de uma proposta de compra de determinada quantidade de um ativo a determinado preço.

Quando o sistema eletrônico de negociação encontra outra equivalente, ou seja, de venda da mesma quantidade daquele título e naquele mesmo preço por outra parte, ele mesmo se encarrega de dar por encerrada essa negociação e entregar automática e eletronicamente à caixa de liquidação o encargo de administrar o adimplemento das obrigações contrapostas da operação.

Como ressaltado anteriormente, no ambiente bursátil são as sociedades corretoras, por interesse próprio ou cumprindo suas obrigações de comissárias dos seus clientes (efetivos agentes econômicos que estão comprando e vendendo direitos), que interagem com as caixas de liquidação.

Nesse contexto, surgem dois outros problemas interessantes de ordem jurídica, intimamente ligados, que são (i) caracterização ou não das ordens de pagamento como propostas aptas a concretizar um negócio anterior à contratação realizada pela caixa de liquidação e (ii) ocorrência ou não da figura da novação quando a caixa de liquidação se coloca como compradora de todos os vendedores e vendedora de todos os compradores, sempre envolvendo negócios firmados por terceiros, nunca pela própria.

Quanto ao primeiro problema: para que as ordens de compra e venda fossem classificadas como propostas, deveriam ser consideradas oferta ao público ${ }^{82}$. Este é um tipo interessante de proposta. O interlocutor não é determinado desde o início, mas determinável. Uma das características da proposta é sua natureza de proteção ao

${ }^{82}$ Código Civil, Art. 429 A oferta ao público equivale a proposta quando encerra os requisitos essenciais ao contrato, salvo se o contrário resultar das circunstâncias ou dos usos. 
interlocutor do proponente, por ter efeito vinculante ${ }^{83}$. Como já dito, no caso da oferta ao público, não há interlocutor certo até que alguém se manifeste. Antes desta manifestação pode mesmo se dizer que há uma proposta, mas que é vazia, já que este instituto possui função precípua de proteção e sem interlocutor determinado não existe a quem proteger.

Logicamente, há vinculação desde o momento em que o participante emana sua ordem com todos os requisitos de uma proposta - objeto, preço, quantidade - mas é preciso perceber um aspecto peculiar sobre a ordem emitida. Esta pode ser cancelada a qualquer momento por seu emitente, pois nunca será conhecida por outro participante, não tendo quem lhe cobre o cumprimento da promessa inicial, ou seja, a ordem - enquanto considerada proposta - é sim vinculante, mas ninguém pode exigir seu cumprimento.

A única hipótese em que um participante se vê obrigado a cumprir sua ordem de compra ou venda é no caso de o sistema de negociação a ter cruzado com outra ordem equivalente. Entretanto, a partir desta circunstância, este encontro é automaticamente enviado para registro, ou seja, já será parte de um contrato e não uma proposta pré-contratual. Isto leva novamente à mesma conclusão, nunca se terá a situação de alguém exigindo o cumprimento de uma ordem enquanto proposta, porque não há possibilidade de ninguém aceitá-la enquanto tal. Como propostas, somente o sistema possui acesso às ordens.

Observe-se que depois do registro, já há contrato. Como o encontro das duas ordens chega ao conhecimento dos participantes já depois de registrada a operação, a desistência neste momento não mais significa uma recusa de cumprimento de proposta, mas um caso de inadimplemento. Desta forma, mostra-se impossível a possibilidade de recusa de cumprimento de proposta.

Diante de tais conclusões, seria possível o seguinte questionamento: uma ordem para o sistema de negociação pode ser considerada uma proposta mesmo sem nunca poder ser aceita por ninguém? Uma proposta que já nasce para nunca ser aceita é somente a exposição dos termos de negociação. Apesar da estranheza que isto pode causar, a resposta à pergunta deve ser afirmativa, já que a possibilidade de aceitação não é um dos

${ }^{83}$ Código Civil, Art. 427 A proposta de contrato obriga o proponente, se o contrário não resultar dos termos dela, da natureza do negócio, ou das circunstâncias do caso. 
requisitos de existência de uma proposta. No entanto, deve se perceber a fragilidade desta proposta, que nem pode ser aceita, nem exerce sua função de proteção.

O que se demonstra é a ineficiência da utilização do instituto da proposta em ambientes em que haja caixas de liquidação, e mais, a forma completamente distorcida como estas propostas se apresentam.

Diante do caminho construído até a resposta ao primeiro problema, é mais fácil encontrar a resposta para o segundo questionamento levantado: da ocorrência ou não da figura da novação quando a caixa de liquidação se coloca como compradora de todos os vendedores e vendedora de todos os compradores, sempre envolvendo negócios firmados por terceiros, nunca pela própria.

Mesmo que se considere uma ordem de compra ou de venda como proposta, esta não seria capaz de permitir o surgimento de um contrato anterior aos contratos firmados sob a custódia da caixa de liquidação. A ordem-proposta não pode ser aceita por um participante individualmente, mas somente dentro do cronograma do sistema, portanto concomitantemente com o registro da operação, ou seja, somente é possível a formação de um único contrato e depois do registro da transação ${ }^{84}$.

SOUZA JÚNIOR ${ }^{85}$ levanta a questão, especulando se nesse caso não estaria configurada delegação subjetiva ou novação. Em sua opinião, a hipótese de delegação subjetiva estaria afastada de plano, dado o caráter definitivo da interposição da clearing entre as partes. Já a existência de processo de novação é defendida diretamente por LEÃES $^{86}$ e indiretamente por SALLES ${ }^{87}$.

\footnotetext{
${ }^{84}$ SOUZA JÚNIOR, op. cit., p. 125.

${ }^{85}$ LOPES, op. cit., p. 122.

${ }^{86}$ LEÃES, Luis Gastão Paes de Barros. Liquidação compulsória dos contratos futuros. Revista dos Tribunais, RT, São Paulo, 1992, nº 675, p.54.

${ }^{87}$ SALLES, Marcos Paulo de Almeida. O contrato futuro. São Paulo: Cultura, 2000.
} 
Os requisitos essenciais da novação estariam presentes nas operações liquidadas pelas clearings. Para FIUZA ${ }^{88}$ são quatro os requisitos desse instituto: (i) consentimento e capacidade, partes livres para decidir se haverá novação; (ii), existência da antiga obrigação, ainda que natural (obligatio novanda); (iii) validade e concomitância, pois com a extinção da antiga obrigação, nascerá uma nova válida; e (iv) animus novandi, ou seja, a intenção de extinguir a primeira obrigação criando outra.

Se poderia ainda existir alguma dúvida acerca da presença do animus novandi, dada a ausência da expressa manifestação pelas contrapartes das caixas de liquidação, é de se entender que isso seria suprido simplesmente pelo fato de ser público e notório para as partes, uma vez que "compradores e vendedores contratam sabendo que, finalisticamente, estarão vinculados à câmara" ${ }^{\text {, }}$.

Entretanto, a estrutura operacional das caixas de liquidação que foi sendo forjada com o aprendizado e os avanços tecnológicos, especialmente após o fim do pregão viva voz, tornou essa discussão caduca, especialmente por eliminar na prática a existência de um primeiro negócio (obligatio novanda) firmado diretamente entre os participantes.

Quando ainda existia o pregão viva voz, de fato as partes negociavam diretamente sem a intervenção de terceiros no ambiente organizado pelas bolsas de valores, só se colocando a caixa de liquidação como contraparte após o registro da operação. Havia claramente, portanto, uma primeira fase e a entrega da liquidação da obrigação para um terceiro.

Mas com a informatização de todo o processo, inclusive na fase de lançamento das ordens de compra e de venda, não existe mais o tal encontro direto das partes, pois as ordens são feitas genericamente para todo o ambiente de negociação, cabendo ao sistema eletrônico da bolsa encaixar os interesses.

\footnotetext{
${ }^{88}$ Op. cit.

${ }^{89}$ GORGA, Érica Cristina R. A importância dos contratos a futuro para a economia de mercado. Revista de Direito Mercantil, Industrial e Industrial Econômico e Financeiro, RT, São Paulo, nº 112, p.193.
} 
Como já enfatizado, nenhum negociante tem acesso aos termos de compra e venda dos outros desde o início, não podendo haver a formação de um contrato, que somente será firmado no momento em que o sistema de negociação cruzar as duas ordens, sem qualquer ação dos respectivos participantes.

Desde o primeiro instante do processo, as partes interagem unicamente com o sistema eletrônico de negociação, plenamente conscientes de que a todo instante farão frente exclusivamente às clearings, não somente quando da liquidação.

Para SOUZA JUNIOR ${ }^{90}$, ademais, a operação só nasce com o registro do encontro das ordens, e no momento do registro a caixa de liquidação já é carreada à negociação como intermediária das partes, inexistindo oportunidade anterior para o relacionamento entre comprador e vendedor.

Restaria, entretanto, ainda a dúvida sobre a existência ou não de um primeiro negócio a ser novado, quando se trata das obrigações contraídas no âmbito das clearings de pagamento. É que, nessas caixas, os lançamentos feitos não são na base de ordens de compra e venda, mas já de efetiva operação de envio e recebimento de recursos pelos participantes.

Noutras palavras, nas clearings atreladas a um ambiente de compra e venda de valores mobiliários, as partes lançam ordens de compra e venda genericamente ao mercado, sem direcionamento específico, até que o sistema de negociação encontre outra inversa que se encaixe.

Já nas clearings de pagamento, as ordens são lançadas por um participante direta e especificamente para outro ${ }^{91}$. Haveria obligatio novanda?

\footnotetext{
${ }^{90}$ Op. cit., p. 125.

${ }^{91}$ Ex.: Banco A ordena a remessa de $\mathrm{R} \$ 1.000$ para o Banco B no STR.
} 
A resposta é não, pois tal como as clearings de suporte ao ambiente bursátil, as caixas de liquidação de pagamentos já estavam presentes servindo de contraparte dos seus membros no momento do lançamento das ordens.

Mesmo porque essas partes aderiram a tal clearing previamente, e é só por conta da existência dela que eles têm como se conectar e realizar a transação. A caixa nem chega a atuar no sentido de organizar o encontro das ordens inversas ${ }^{92}$, pois serve apenas de instrumento de conexão entre os membros.

Somente há um único contrato, já firmado diretamente com a caixa de pagamento, para que esta se encarregue dos repasses solicitados. No Direito Comparado, todavia, há muitos registros dando conta de que no ordenamento jurídico de alguns países a interposição da clearing entre as partes é interpretada como novação ${ }^{9394} 95$.

Finalmente, outra questão jurídica importante relacionada ao funcionamento das clearings é o que diz respeito à organização das obrigações contraídas pelas partes no ambiente de negociação das bolsas de valores.

Os participantes continuamente adotam posições de credores e devedores das câmaras de liquidação. Para facilitar a dinâmica, estabelece-se entre cada um deles, e a caixa de liquidação respectiva, uma relação jurídica de conta corrente, com ajuste e pagamento de saldo a cada dia ${ }^{96}$.

\footnotetext{
${ }^{92}$ Como fazem os sistemas de negociação das bolsas de valores.

${ }^{93}$ HASENPUSCH, Tina P. Clearing services for global markets: a framework for the future development of the clearing industry. Cambridge: 2009. p.23.

${ }^{94}$ MILLS, Annie. Essential strategies for financial services compliance. Chichester (UK): John Wiley and Sons, 2008. p.70.

${ }^{95}$ NIEUWENHUIJZEN. Financial Law in the Netherlands. Alphen: Kluwer Law International, 2010. p.106.

${ }^{96} \mathrm{Ou}$ a cada período maior ou menor previsto nos normativos de cada caixa de liquidação.
} 
Como as operações são sucessivas e recíprocas, com anotações de partidas contábeis de crédito e débito, o caminho natural seria a utilização da figura jurídica da compensação bilateral, prevista no art. 368 do Código Civil ${ }^{97}$.

De acordo com DINIZ ${ }^{98}$, a compensação bilateral ocorre quando dois indivíduos são simultaneamente credores e devedores um do outro e realizam o encontro de contas, solvendo suas dívidas vencidas e líquidas reciprocamente. A compensação poderá ser total ou parcial, sendo que neste último caso uma das partes resultará devedora de um saldo remanescente.

Todavia, considerando que as caixas de liquidação atuam em ambientes controlados, com agentes identificáveis, opta-se pelo interessante instituto da compensação multilateral, instituída expressamente no ordenamento jurídico brasileiro pelo art. $3^{\circ}$ da Lei $10.214 / 2001^{99}$.

PEREIRA FILHO ${ }^{100}$ ressalta que a compensação multilateral é um novel instituto trazido com a organização do Sistema de Pagamento Brasileiro, destacando que deve ser realizada por caixas de liquidação centralizadoras e pode contemplar também dívidas futuras.

Por meio da compensação multilateral, na prática a caixa de liquidação apura a soma total dos haveres e deveres de cada participante em relação a cada um dos outros, de forma a constituir um saldo final único individual a ser lançado a crédito ou débito na conta de titularidade de cada um.

\footnotetext{
${ }^{97}$ Lei 10.406/2002, art. 368: "Se duas pessoas forem ao mesmo tempo credor e devedor uma da outra, as duas obrigações extinguem-se, até onde se compensarem".

98 Diniz, Maria Helena. Curso de direito civil brasileiro: teoria geral das obrigações. 21.ed. São Paulo: Saraiva, 2006.

${ }^{99}$ Lei 10.214/2001, art. 30. "É admitida a compensação multilateral de obrigações no âmbito de uma mesma câmara ou prestador de serviços de compensação e de liquidação.

Parágrafo único. Para os efeitos desta Lei, define-se compensação multilateral de obrigações o procedimento destinado à apuração da soma dos resultados bilaterais devedores e credores de cada participante em relação aos demais."

${ }^{100}$ Op. cit.
} 
Tal sistemática se mostra bem mais interessante que a das compensações bilaterais, sobremaneira do ponto de vista da economicidade e da eficiente alocação de recursos, uma vez que não demanda desencaixe financeiro imediato a cada operação fechada pelos participantes, mas tão somente do saldo final dos seus negócios de compra e venda.

Além da liquidação por compensação, as clearings também podem liquidar por diferença, típica dos mercados futuros e que se baseia no efetivo cumprimento da obrigação estipulada, com a entrega pelo devedor da diferença entre o preço ou valor do objeto previsto contratualmente e sua real cotação na data do pagamento. Ocorre, pois, um efetivo pagamento, e não a compensação entre obrigações mútuas e equivalentes.

Além da tradicional função de liquidar as obrigações assumidas pelos participantes no seu ambiente de negociação, as caixas de liquidação também podem prestar outros serviços adicionais de grande relevância, de que se tratará mais adiante. 


\subsubsection{Custódia de ativos}

A típica função adicional das caixas de liquidação, especialmente quando se trata de negócios envolvendo valores mobiliários, é a custódia dos títulos negociados, sejam eles materializados ou, como se observa quase sempre, escriturados eletronicamente.

O casamento entre a liquidação com a custódia de ativos é, sem dúvidas, um inteligente e eficiente acúmulo de funções, pois a clearing pode não só garantir o pagamento das operações, por já administrar e guardar consigo as garantias financeiras, mas também a entrega dos bens negociados, por estarem sob sua custódia. Isso confere maior segurança e rapidez na liquidação financeira e na transferência da titularidade dos valores mobiliários.

Após a extinção da figura das ações ao portador pela Lei 8.021/1990, a CVM publicou a Instrução 115/90, que criou a custódia fungível das ações nominativas, que se encontra em funcionamento até os dias atuais.

Na prática, uma instituição devidamente autorizada pela CVM passa a ser depositária dos títulos e valores mobiliários, em regime de propriedade fiduciária, responsabilizando-se por manter atualizado o cadastro dos titulares das ações sob sua responsabilidade ${ }^{101}$.

Para uma maior segurança dos ambientes de negociação de títulos e valores mobiliários, essa função de custodiante normalmente é delegada compulsoriamente às clearings, ou seja, uma custodiante necessária dos valores negociados em bolsa.

A transferência de titularidade dos papéis entre os sucessivos vendedores e compradores se baseia no sistema de book entry transfer $^{102}$. Por essa sistemática, torna-se desnecessária a averbação de cada transferência no Livro de Registro de Ações da Companhia, que terá consigo apenas o registro de que os títulos estão sob propriedade

\footnotetext{
${ }^{101}$ Instrução CVM 115/1990.

102 Tradução livre: transferência por registro escritural.
} 
fiduciária da clearing, que se responsabiliza por saber e informar sobre a titularidade de cada valor continuamente.

Também nos Estados Unidos e União Européia o serviço de custódia é prestado pelas clearings ${ }^{103}$ por meio do sistema book-entry, principalmente quanto a títulos desmaterializados.

${ }^{103}$ As bolsas de valores mais importantes delegam essa atividade à Central Security Depositories. 


\subsubsection{Gerenciamento de riscos e garantias}

Para que as câmaras de liquidação possam assumir a posição de contraparte garantidora de todas as operações entabuladas no seu âmbito, é evidente que um eficaz mecanismo de avaliação da exposição dos agentes ao inadimplemento precisa ser implementado.

Assim, para que um participante possa operar com uma clearing, deve primeiramente aportar um determinado volume de garantias na forma de margens, valor utilizado como base para o cálculo do seu limite operacional.

Cabe à câmara administrar as garantias que lhe são oferecidas, calcular o grau de exposição dos agentes e exigir eventuais aportes adicionais, além de estabelecer os critérios para a admissão de novos participantes, no exercício do seu poder de autoregulação ${ }^{104}$

Essa dinâmica segue a lógica adotada nos Estados Unidos, onde,

"in order to protect themselves against the risks emerging from a clearing member's default, clearing houses typically apply a range of risk management procedures.

In particular, every clearing member must post an initial amount with the clearing house as margin (initial margin) upon the creation of a position. The margin necessary to secure each position is then recalculated at least once a day and, at many exchanges, more often per day, with any additionally required margin (maintenance margin) having to be paid accordingly.

The kinds of assets that may be posted as initial and maintenance margin are specified by the clearing house and generally include cash, government securities and bank guarantees or letters of credit. More and more often, clearing houses are also accepting shares in money market mutual funds

\footnotetext{
${ }^{104}$ A doutrina entende que a auto-regulação se faz conveniente quando coexistirem três fatores: falha ou risco relevante em determinado sistema, ineficiência dos instrumentos legais tradicionais para mitigar essa falha ou risco, e o custo da regulação ser menor que o prejuízo iminente da sua não adoção.
} 
and listed equities as initial margin. Variation margin is typically paid in cash ${ }^{105}$.

Ressalte-se que a câmara não honra os negócios firmados além do limite operacional, que é calculado de acordo com critérios próprios de cada caixa de liquidação, tomando por base, principalmente, o volume e a liquidez dos ativos aportados pelos participantes, na medida em que esse limite é a "extensão da sua responsabilidade"106.

Cada participante tem acesso ao limite operacional de todos os outros, bem como ao nível de exposição consumido a cada instante. Na prática, o que se verifica é que negócios não cobertos pela câmara simplesmente não são firmados, não só pelo fato de as corretoras não se arriscarem gratuitamente, mas também porque cabe às caixas de liquidação idealmente nem darem oportunidade para isso acontecer.

Enquanto organizadoras do ambiente de negociação, as bolsas de valores também exercem papel fiscalizador e, observando as informações prestadas pelas clearings acerca do volume utilizado das margens de garantia pelos participantes, terminam por replicar uma instância adicional de segurança.

Ainda assim, caso haja o inadimplemento das obrigações de determinado participante junto à caixa de liquidação, esta sempre as honrará perante os demais agentes.

Se as margens de garantia da inadimplente forem insuficientes para a cobertura dos seus deveres, aplica-se o fenômeno do survivors pay, ou seja, os demais participantes arcam com o prejuízo.

\footnotetext{
105 Tradução livre: com o intuito de se proteger do risco decorrente do inadimplemento de seus participantes, as caixas de liquidação geralmente aplicam um conjunto de regras de gestão de riscos.

Especificamente, cada membro de uma caixa de liquidação deve depositar junto às mesmas uma quantia inicial como margem de segurança ou garantia (margem inicial) para que se efetive sua participação.

A margem de segurança necessária para garantir cada participação é, então, recalculada pelo menos uma vez por dia e, no caso de muitos mercados, mais de uma vez por dia, com a posterior possibilidade de exigência de qualquer acréscimo que seja necessário (margem de permanência), que deve ser paga adequadamente.

Os tipos de ativos que podem ser depositados como margem inicial e de permanência são especificados pelas caixas de liquidação e geralmente incluem dinheiro, títulos estatais e garantias bancárias ou cartas de crédito. Cada vez mais, as caixas de liquidação também têm aceitado ações em fundos mútuos de mercado de câmbio e listando ações como margem inicial. A variação de margem é geralmente paga em espécie (RUSSO, Daniela et al. op.cit.).

${ }^{106}$ PEREIRA FILHO, op. cit.
} 
Apenas em último caso, o patrimônio da caixa de liquidação, que tem destinação especial e é blindado contra os regimes comuns de insolvência (falência, liquidação, intervenção etc.), responderia pelo adimplemento, como se verá adiante. 


\section{CLASSIFICAÇÃO DAS CLEARINGS}

Não foi identificada na doutrina brasileira uma classificação expressa das caixas de liquidação, mas há registros no Direito norte-americano.

Para THRALLS ${ }^{107}$, as clearings se dividiriam de acordo com sua forma de organização societária: companhias ou organizações voluntárias, que no Brasil encontram nas associações civis sem fins lucrativos sua figura correspondente. Interessante que na época (1916) o autor não via vantagem na organização das clearings na forma de sociedade empresária.

Já CANNON $^{108}$ classificou as caixas de liquidação com base em dois critérios: (i) funções da caixa, existindo aquelas que apenas liquidavam obrigações e as que, além disso, prescreviam regras de controle dos seus participantes; e (ii) de acordo com os tipos de pagamento aceitos no acerto dos saldos, havendo as clearings que só aceitam dinheiro e aquelas que também acatavam títulos de crédito (mormente cheques) para a liquidação das obrigações dos seus participantes devedores.

No Brasil, pela análise histórica das caixas de liquidação e a partir da sua própria definição e principais características, é possível classificá-las com base em alguns critérios, como se verá a seguir.

Tal classificação não se impõe meramente por preciosismo teórico, mas fundamentalmente porque o tipo de clearing pode definir, por exemplo, a qual regime jurídico de quebra ela está sujeita.

${ }^{107}$ THRALLS, Jerome. The clearing house. Nova York: American Bankers Association, 1916. p.2.

108 CANNON, James Graham. Clearing-houses: their history, methods, and administration. Nova York: Appleton, 1908. p.2. 


\subsection{Objeto negociado}

\subsubsection{Clearings de pagamentos (ou de fundos)}

São as caixas de liquidação que operam com pagamentos e transferências simples, normalmente sem vinculação a algum ativo ou recurso específico. É o caso do Sistema de Transferência de Reservas do BaCen, no qual transitam ordens eletrônicas de crédito e débito entre instituições financeiras e outros participantes que têm acesso ao sistema.

No âmbito das caixas de liquidação privadas, merecem destaque o Sistema de Liquidação Diferida das Transferências Interbancárias de Ordens de Crédito (SILOC) e o estreante Sistema de Controle de Garantias (SCG), ambos geridos pela Câmara Interbancária de Pagamentos (CIP). Os participantes convencionaram que na primeira seriam liquidadas as transferências interbancárias decorrentes de DOCs ${ }^{109}$ e pagamentos de boletos bancários.

O SCG é a mais nova caixa de liquidação do Sistema de Pagamentos Brasileiro, tendo sido instituída em $1^{\circ}$ de julho de $2010^{110}$ com a finalidade de concentrar a compensação das obrigações decorrentes do uso de cartões de crédito administrados por quaisquer emissores, de quaisquer bandeiras e em quaisquer estabelecimentos vinculados aos diversos credenciadores.

\subsubsection{Clearings de títulos de crédito}

São as clearings que operam com títulos cambiariformes em circulação no Sistema Financeiro Nacional, como a Centralizadora da Compensação de Cheques ${ }^{111}$,

\footnotetext{
${ }^{109}$ Documento de Ordem de Crédito, que é uma transferência de valores entre correntistas de instituições financeiras diferentes, cujo valor máximo na atualidade está fixado em $\mathrm{R} \$ 2.999,99$ e é liquidado um dia útil após a remessa.

110 Por ocasião da assinatura da Convenção Para Regulamentação e Proteção de Garantias entre a FEBRABAN, ABECS, ABBI, ABBC, ACREFI e CIP.

${ }^{111}$ COMPE.
} 
responsável pela liquidação das obrigações interbancárias decorrentes de cheques de valor inferior a $\mathrm{R} \$ 250.000$.

Visto que a COMPE liquida papéis, ela dispõe não só de um sistema eletrônico, mas de toda uma estrutura física para o trânsito dos documentos, atualmente formada por uma câmara nacional, quinze regionais e dez locais, operadas pelo Banco do Brasil em nome do BaCen.

\subsubsection{Clearings de câmbio}

Trata-se das caixas que liquidam negócios envolvendo moeda estrangeira. No Brasil, a principal clearing de câmbio é a da BMF\&BOVESPA, onde são realizados negócios de compra e venda de dólar estadunidense com liquidação normalmente em D+2, de acordo com suas normas internas.

Por envolverem negócios entre moedas, a liquidação ocorre pela sistemática do pagamento contra pagamento, ou seja, a entrega da moeda estrangeira comprada fica condicionada à entrega da moeda nacional, processo coordenado pela BMF\&BOVESPA, que se coloca como contraparte central operadora da compensação multilateral.

\subsubsection{Clearings de valores mobiliários}

São espécies de clearings por vezes confundidas com a própria definição genérica de caixa de liquidação, hipoteticamente por serem as mais numerosas e conhecidas pelos agentes de mercado, em detrimento, por exemplo, das câmaras de pagamento, normalmente invisíveis ao homem médio. É de se imaginar que a grande maioria dos correntistas não faz idéia da existência do SILOC para liquidar as corriqueiras operações de remessa de recursos entre contas de bancos diversos por meio do DOC.

Por outro lado, indivíduos que investem no mercado de valores mobiliários normalmente sabem da existência da CBLC, normalmente por conhecerem um pouco mais 
os mecanismos existentes nessa área e receberem dessa câmara, de forma regular, seu extrato de transações e títulos custodiados.

Além disso, conforme já citado neste trabalho, historicamente percebe-se que também no meio acadêmico as caixas de liquidação mereceram citação, no mais das vezes, por estudos relacionados ao mercado de valores mobiliários. Por tal motivo, o foco da atenção sempre foi o das clearings de valores mobiliários, sem grande destaque às liquidantes de outros negócios. Disso tudo decorre a freqüente mistura e generalização entre o gênero clearing com a espécie clearing de valores mobiliários.

No Brasil, muitos são os exemplos de caixas que liquidam valores mobiliários, como a CBLC (ações, títulos privados, opções etc.), CETIP (títulos privados, swaps etc.) e a Câmara de Derivativos da BMF\&BOVESPA (mercadorias, futuros, swaps etc.).

Nos Estados Unidos a Depository Trust \& Clearing Corporation $(D T C C)^{112}$, por meio de uma série de subsidiárias, é a responsável pela liquidação da maioria dos negócios envolvendo diversos valores mobiliários, tendo movimentado em 2009 em torno de 1,48 quatrilhões de dólares ${ }^{113}$. Outra importante caixa de liquidação é a Options Clearing Corporation (OCC), liquidante de opções e futuros.

Já na Europa, as principais caixas de liquidação de valores mobiliários são a Euroclear e a Clearstream.

${ }^{112}$ Companhia Depositária e de Liquidação, em tradução livre.

113 The Depository Trust \& Clearing Corporation. Annual Report 2009. Disponível em: <http://www.dtcc.com/downloads/annuals/2009/2009_report.pdf>. Acesso em 13/12/2010. 


\subsection{Forma de adesão}

\subsubsection{Compulsória}

A adesão à clearing é compulsória quando a participação é obrigatória e decorrente de determinação legal ou regulamentar. No SPB, o exemplo mais emblemático é o dos bancos comerciais, bancos múltiplos com carteira comercial e das caixas econômicas, que devem ser titulares de uma conta de reservas bancárias junto ao Sistema de Transferência de Reservas ${ }^{114}$.

Essa obrigatoriedade normalmente é imposta com o objetivo de submeter certos agentes econômicos à fiscalização de um ente regulador. No caso das instituições financeiras supracitadas, a participação compulsória no STR as coloca no raio de estrita fiscalização pelo BaCen, pois este não só é o depositário das reservas bancárias, mas também o gestor do STR.

Outro caso de adesão compulsória digno de nota é o que ocorre nas caixas de liquidação atreladas a determinado ambiente de negociação, como a Companhia Brasileira de Liquidação e Custódia, nomeada pela BMF\&BOVESPA como câmara de liquidação dos negócios entabulados na bolsa ${ }^{115}$.

Assim, para que uma corretora possa operar nesse ambiente, deverá primeiramente aderir à CBLC para liquidar suas transações nessa câmara, não podendo fazê-lo em local ou sistema estranho.

$\mathrm{Na}$ verdade, em termos práticos, essa possibilidade foi um tanto quanto mitigada, por conta da automatização não só da liquidação, mas também da negociação. Com o fim do pregão viva voz, todas as ofertas de compra e de venda que iniciam os negócios realizados na BMF\&BOVESPA são inseridas num sistema eletrônico próprio que já se encarrega de entregá-los à CBLC para liquidação, assim que fechados.

\footnotetext{
${ }^{114}$ Circular BaCen 3.438/2010, art. $4^{\circ}$, I.

${ }^{115}$ Regulamento de Operações do Segmento BOVESPA: ações, futuros e derivativos de ações (dez/2008).
} 
Bom, é certo que as corretoras não são obrigadas a operar na BMF\&BOVESPA, mas a compulsoriedade sob comento é a da adesão à caixa de liquidação. No exemplo citado, por definição regulamentar, a participação da corretora na CBLC será compulsória, se decidir operar no ambiente de negociação dessa bolsa.

\subsubsection{Facultativa}

Outras caixas de liquidação são de adesão facultativa, ou seja, seus membros decidiram livremente nelas ingressar, não em decorrência de uma condição.

Pode ser citado o caso de instituição financeira que decide instituir uma carteira de crédito composta por Cédulas de Crédito Bancário emitidas por seus clientes em seu favor ${ }^{116}$. Trata-se de livre decisão comercial.

Por definição, como já dito, os bancos com carteira comercial devem aderir obrigatoriamente ao STR, mas não à CETIP, pois eles poderiam operar com outras finalidades que não a de trabalhar com títulos passíveis de registro nessa câmara.

Há registro de banco múltiplo ${ }^{117}$ com carteira comercial que até bem pouco tempo não operava com esses títulos, focando suas atividades unicamente na exploração do negócio de recebimento de contas em seus correspondentes bancários ${ }^{118}$. Sua participação na CETIP era, pois, facultativa.

\footnotetext{
${ }^{116}$ Sujeita a registro na CETIP, conforme Resolução CMN 1.779/1990.

${ }^{117}$ Lemon Bank, atual Banco Lemon.

${ }^{118} \mathrm{Na}$ forma da Resolução CMN 3.110/2003.
} 


\subsection{Serviços prestados}

\subsubsection{Clearing houses puras}

São as caixas de liquidação que exercem apenas sua atividade principal de liquidação das obrigações entabuladas pelos seus participantes, não oferecendo ao mercado outros serviços agregados.

\subsubsection{Clearing houses mistas}

Além do seu serviço fundamental de liquidação das operações, as câmaras mistas realizam outras atividades adicionais, como a custódia de títulos e valores mobiliários.

\subsection{Forma de organização}

$\mathrm{Na}$ atualidade, esse critério de classificação encontra-se meio que caduco no Brasil, uma vez que por expressa determinação legal as caixas de liquidação devem se organizar na forma de sociedades anônimas. Ou seja, essa é a sua forma de organização mandatória.

Antes, porém, as clearings no Brasil podiam se estruturar na forma de associações civis sem fins lucrativos, tal como as bolsas de valores antes do recente fenômeno de desmutualização. Também eram comuns as caixas de liquidação sem personalidade jurídica autônoma, estruturadas como departamentos internos de outras entidades.

Há, finalmente, uma figura diferente das caixas de liquidação personificadas, que são os sistemas de liquidação geridos diretamente pelo BaCen. Não existe na regulação a menção expressa à forma de organização, por exemplo, do STR e do SELIC. 
Pelo que se depreende do seu funcionamento e do espírito dos seus regulamentos, eles são apenas sistemas eletrônicos executados e geridos pelo BaCen, não sendo dotados de personalidade jurídica própria.

A forma de organização das caixas de liquidação exerce um papel muito importante no âmbito da definição do regime jurídico ao qual elas se sujeitam. As clearings organizadas como sociedades empresárias, no que tange a legislação de quebras, se sujeita à disciplina da Lei de Recuperação e Falência, o que não ocorre com as associações civis sem fins lucrativos e as clearings geridas diretamente pelo BaCen e organizadas na forma de sistema eletrônico de acesso. 


\section{AS CLEARINGS NO SISTEMA DE PAGAMENTOS BRASILEIRO}

O Sistema de Pagamentos Brasileiro - SPB, instituído pela Lei 10.214/2001 (Lei do SPB), engloba as entidades, os sistemas e os procedimentos relacionados com a transferência de fundos e de outros ativos financeiros, ou com o processamento, a compensação e a liquidação de pagamentos em qualquer de suas formas ${ }^{119}$.

Até o advento da Lei do SPB, a liquidação das operações e negócios realizados no mercado financeiro era feita através de lançamentos diretamente nas contas de reservas bancárias mantidas no Banco Central.

Por tal sistemática, o Banco Central assumia o risco de inadimplência dos participantes do mercado, pois somente no final do dia era feito o fechamento do saldo que, quando fosse devedor, ou seria suportado pela autarquia ou seria zerado mediante cancelamento compulsório das operações inadimplidas, ou seja, seria "perdoado".

Era uma faca de dois gumes, pois ou o erário assumia o ônus inteiro do inadimplemento dos particulares, ou potencializaria e devolveria ao mercado todo o risco sistêmico do desfazimento de uma cadeia inteira de obrigações.

Isso considerando, por óbvio, que o inadimplente terá entabulado diversos outros negócios com outras partes se utilizando dos recursos da reserva descoberta. Neste cenário, poderia ser desencadeada uma quebradeira com efeito dominó.

Com a Lei do SPB, o Brasil se adequou às melhores práticas internacionais de aumento da solidez do sistema financeiro, em termos de adimplemento de obrigações. Transferiu-se ao setor privado o risco gerado por ele mesmo e que antes era assumido pelo Banco Central.

${ }^{119}$ Art. $2^{\circ}$, Lei $10.214 / 2001$. 
Melhor ainda: instituiu-se um sistema formado por diversas caixas setoriais de liquidação, confinando os riscos de cada segmento econômico onde foram gerados, evitando a contaminação do mercado em geral.

Entre tais câmaras, como já citado en passant, uma foi dedicada à liquidação das obrigações envolvendo reservas bancárias: o Sistema de Transferência de Reservas - STR. Seu funcionamento se baseia no regime de Real Time Gross SettlementRGTS $^{120}$, ou seja, qualquer lançamento só é aceito pelo sistema se tiver saldo imediato disponível.

Na prática, um participante do STR só pode transferir para outro os recursos que tiver no exato momento da transação na sua conta de reservas junto ao Banco Central. O sistema simplesmente rejeita qualquer ordem de transferência que não conte com o devido respaldo de saldo disponível imediatamente.

A grande problemática do RGTS é a conseqüente imposição de barreiras à liquidez, ou seja, os participantes desse sistema passaram a ter um limite objetivo das alavancagens que poderiam fazer com seus recursos, atrelado ao seu saldo imediato disponível. Isso naturalmente encareceu o custo para os participantes, pois no âmbito do STR eles não poderiam mais comprar títulos, por exemplo, com lastro em recebíveis futuros.

Para evitar o engessamento do mercado financeiro, que se baseia muito na alavancagem de recursos com base em provisões de recebimento futuro, o SPB também contempla outras câmaras de liquidação baseadas na sistemática Deferred Net Settlement $\mathrm{DNS}^{121}$.

Por esse esquema, os participantes têm flexibilidade para lançar suas operações e acertarem o saldo a cada lapso temporal pré-determinado, mediante sensibilização isolada das reservas bancárias.

\footnotetext{
${ }^{120}$ Em tradução livre: liquidação pelo valor bruto em tempo real (ou LBTR).

${ }^{121}$ Em tradução livre: liquidação diferida pelo valor líquido (ou LDL).
} 
No momento do acerto do saldo resultante dos créditos e débitos de cada participante nas câmaras em DNS, é aberta uma janela de conexão entre tal clearing e a STR, sendo aí sim feita a transferência de recursos dos devedores para os credores naquele exato momento.

No caso de insuficiência de reservas, a clearing setorial arca com o inadimplemento, ou seja, afasta-se o risco sistêmico, pois cada segmento do mercado financeiro arca isoladamente com seus riscos.

De uma forma geral, o diagrama abaixo expõe a atual estrutura do Sistema de Pagamentos Brasileiro:

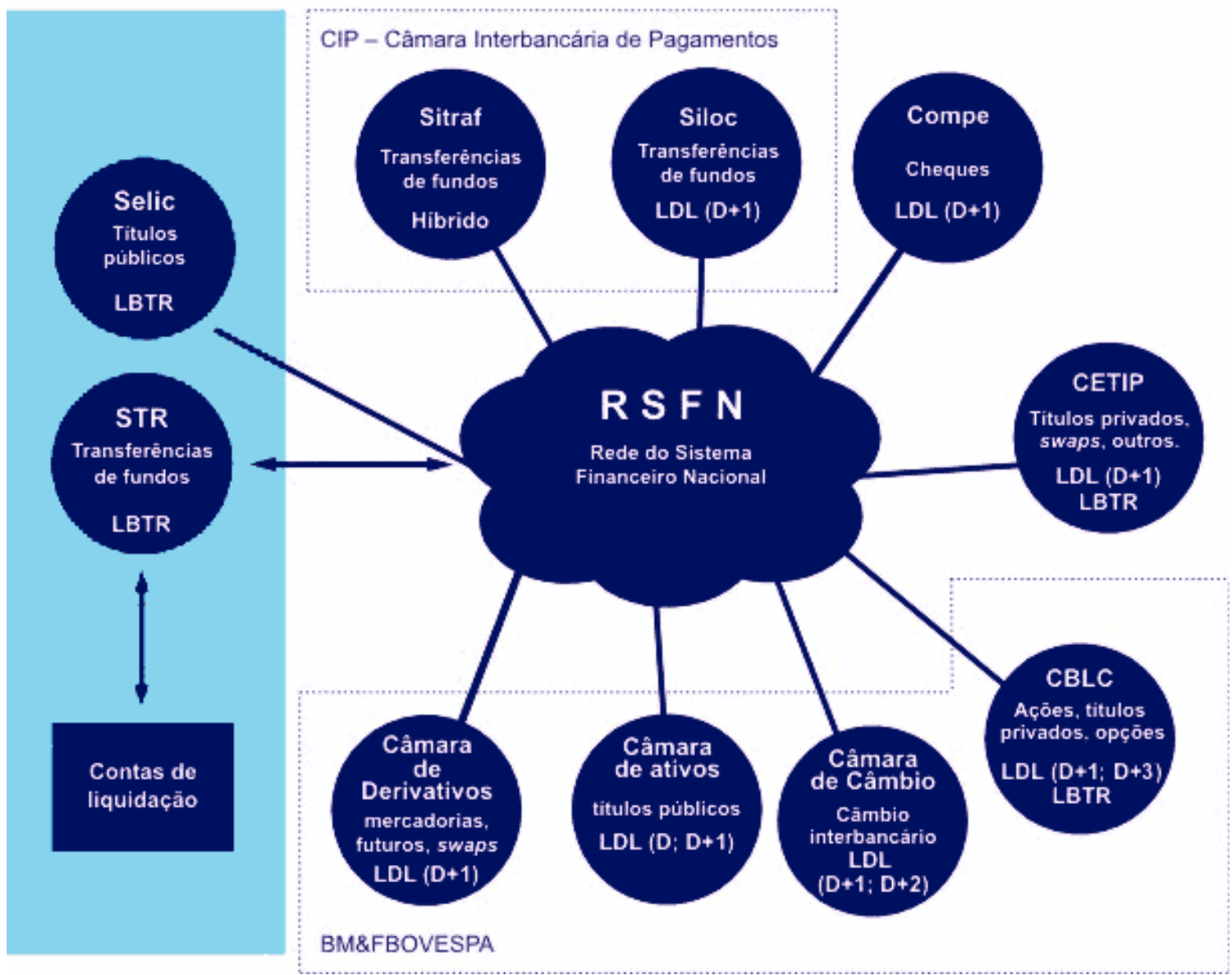

Nele, estão expostas as principais caixas de liquidação sistemicamente importantes para o SPB, com destaque para o seu regime de liquidação (LDL, LBTR ou 
híbrido). Note-se a separação das clearings por grupos de entidades afins, como o SITRAF e o SILOC, geridos pela CIP.

Essa segmentação é interessante especialmente por conta do confinamento dos riscos envolvidos nas operações no seu local de origem. Um default relevante ocorrido no SILOC, por exemplo, ficará restrito a esse sistema, não contaminando o restante do sistema financeiro quando da abertura da janela de transferências com as outras caixas de liquidação.

Considera-se vitoriosa a implementação do SPB com todas essas funcionalidades estruturais que têm funcionado a contento. Se antigamente uma instituição financeira conseguia operar quebrada por semanas até que o BaCen percebesse, hoje nenhum banco pode se expor além das suas disponibilidades, e seus problemas de liquidez são monitorados continuamente em tempo real pela autoridade reguladora.

Dado o sucesso do SPB, o BaCen vem trabalhando na implementação total do SPB2, que ao invés de focar na infra-estrutura do sistema de liquidação, cuidará da modernização e popularização dos meios de pagamento eletrônicos, especialmente os utilizados no varejo.

O BaCen pretente com o SPB2 estimular a interoperabilidade entre as redes operadas isoladamente pelos bancos, prestadores de serviços de compensação e setor não financeiro. O objetivo é o de distribuir de forma inteligente a capacidade operacional ociosa das redes e sistemas geridos isoladamente, por exemplo, pelos bancos ${ }^{122}$.

Na prática, o desafio que se impõe na atualidade é fomentar a cooperação entre os agentes econômicos que participam do SPB para atuarem de forma conjunta, incrementando a eficiência e a segurança dos meios de pagamento.

O primeiro grande movimento decorrente do SPB2 e perceptível pelo cidadão foi a quebra do duopólio do credenciamento de estabelecimentos e gestão de rede

${ }^{122}$ Redes de caixas eletrônicos, por exemplo. Nos Estados Unidos os caixas de auto-atendimento de todos os bancos são interligados, ou seja, qualquer correntista de qualquer banco pode utilizar o caixa eletrônico de qualquer IF. 
de recebimento de cartões de crédito e débito, ocorrido em $1^{\circ}$ de julho de 2010 . Os resultados serão observados com o tempo, mas imagina-se que será uma experiência positiva, dado o sucesso já consolidado nos Estados Unidos e União Européia. 


\section{AS CLEARINGS E O REGIME FALIMENTAR}

Seguindo a tendência mundial de preservação da integridade das operações realizadas e das garantias aportadas nas câmaras de liquidação, o legislador brasileiro, ao disciplinar em 2005 o atual regime falimentar e de recuperação, blindou as clearings dos efeitos do regime concursal.

Em verdade, a Lei do SPB já previa essa blindagem no seu artigo $7^{\circ}$, que prevê o seguinte:

\footnotetext{
"Os regimes de insolvência civil, concordata, intervenção, falência ou liquidação extrajudicial, a que seja submetido qualquer participante, não afetarão o adimplemento de suas obrigações, assumidas no âmbito das câmaras ou prestadores de serviços de compensação e de liquidação, que serão ultimadas e liquidadas pela câmara ou prestador de serviços, na forma de seus regulamentos.

Parágrafo único. O produto da realização das garantias prestadas pelo participante submetido aos regimes de que trata o caput, assim como os títulos, valores mobiliários e quaisquer outros seus ativos, objeto de compensação ou liquidação, serão destinados à liquidação das obrigações assumidas no âmbito das câmaras ou prestadores de serviços".
}

A norma de regência da recuperação e falência ${ }^{123}$ veio apenas reforçar a absoluta proteção das clearings dos efeitos da insolvência dos seus participantes:

"Art. 193. O disposto nesta Lei não afeta as obrigações assumidas no âmbito das câmaras ou prestadoras de serviços de compensação e de liquidação financeira, que serão ultimadas e liquidadas pela câmara ou prestador de serviços, na forma de seus regulamentos.

Art. 194. O produto da realização das garantias prestadas pelo participante das câmaras ou prestadores de serviços de compensação e de liquidação financeira submetidos aos regimes de que trata esta Lei, assim como os títulos, valores mobiliários e quaisquer outros de seus ativos objetos de compensação ou liquidação serão destinados à liquidação das obrigações assumidas no âmbito das câmaras ou prestadoras de serviços”.

Fica explícito, portanto, que, quando um agente econômico falir, por exemplo, seus ativos que foram aportados na forma de margens de garantia junto a alguma clearing serão utilizados única e exclusivamente para a liquidação das suas obrigações

${ }^{123}$ Lei $11.101 / 2005$ 
naquela câmara. Havendo eventual saldo remanescente após o adimplemento das suas obrigações, ele será apurado e entregue para o ativo da massa falida.

Por outro lado, se as garantias aportadas forem insuficientes para o adimplemento das obrigações do falido entabuladas na clearing, esta se habilitará na falência na condição de credora quirografária, sujeitando-se às demais disposições da Lei $11.101 / 2005$.

É minoritária a posição doutrinária de Manoel Justino, que entende como descabida a blindagem das clearings dos efeitos da Lei de Recuperação e Falência, por ser uma suposta violação ao princípio da par conditio creditorum induzida por um "lobby do mercado financeiro".

Todavia, pela relevante função sistêmica desempenhada pelas câmaras de liquidação, fica claro que as garantias que lhe são oferecidas não operam em seu favor, mas para dar lastro às operações dos seus participantes, com vistas a conferir higidez, fluidez e eficiência a todo o sistema financeiro.

Na União Européia, desde a Diretiva 98/26/CE, não existe qualquer dúvida acerca do caráter definitivo da liquidação nos sistemas de pagamento e de liquidação de valores mobiliários, sendo assegurada a blindagem e manutenção das garantias aportadas nas clearings mesmo nos regimes de insolvência ${ }^{124}$.

Já no Canadá, por conta do disposto no Capítulo 13.1 do Payment, Clearing and Settlement Act ${ }^{125}$, de 1996 (alterado em 2002), é dada às clearings plena liberdade de excussão das garantias nelas aportadas, sem margem para interpretações diversas.

\footnotetext{
124 “Article 3 (1). Transfer orders and netting shall be legally enforceable and, even in the event of insolvency proceedings against a participant, shall be binding on third parties, provided that transfer orders were entered into a system before the moment of opening of such insolvency proceedings as defined in Article 6(1)."

125 “13.(1) Notwithstanding anything in any law relating to bankruptcy or insolvency or any order of a court made pursuant to an administration of a reorganization, arrangement or receivership involving insolvency, where a financial institution or the Bank is a party to a netting agreement, the financial institution or the Bank may terminate the agreement and determine a net termination value or net settlement amount in accordance with the provisions of the agreement and the party entitled to the net termination value or settlement amount is to be a creditor of the party owing the net termination value or net settlement amount for that value or amount."
} 
Também é importante citar as recomendações feitas pelo BIS por meio do Core Principles for Systemically Important Payment Systems, que destaca os princípios gerais norteadores do funcionamento da liquidação financeira, sempre baseados na idéia de que o elemento de fortalecimento do sistema é a exigibilidade do cumprimento das obrigações em quaisquer circunstâncias, mesmo na insolvência de quaisquer envolvidos.

No que diz respeito às obrigações assumidas pelas caixas de liquidação perante seus participantes e o mercado, o que se conclui da análise da lei de recuperação e falência é que esta não exclui expressamente as clearings do rol de sociedades quebráveis. Ou seja, em que pese o ineditismo da hipótese no Brasil, as caixas de liquidação seriam quebráveis, porquanto organizadas na forma de sociedades anônimas, por determinação legal.

Essa é realmente uma observação muito interessante, que induz o autor a inferir que a mens legis da obrigatoriedade de organização das clearings como companhias, entre outros motivos, compreendeu a idéia de torná-las quebráveis, afastandoas do limbo da liquidação judicial. 


\section{CONCLUSÕES}

\subsection{CONCLUSÃO A PARTIR DO DIREITO COMPARADO}

Para os fins deste trabalho, foram estudados os três mais importantes documentos balisadores das melhores práticas no âmbito das liquidações financeiras, elaborados pelo BIS e pela IOSCO: (i) Recommendations for Central Counterparties $^{126}$; (ii) Core Principles for Systemically Important Payment Systems ${ }^{127}$; e (iii) Recommendations for Securities Settlement Systems ${ }^{128}$.

Merecem especial destaque as Recomendações para os Intermediários de Mercado (Central Counterparties ou $C C P)^{129}$, comentadas a seguir:

126 Tradução livre: Recomendações para os Intermediários de Mercado. Disponível em: <http://www.iosco. org/library/pubdocs/pdf/IOSCOPD176.pdf>. Acesso em 10/9/2010.

127 Tradução livre: Princípios Fundamentais dos Sistemas de Pagamento Sistemicamente Importantes. Disponível em: <http://www.bis.org/publ/cpss43.pdf>. Acesso em: 11/9/2010.

128 Tradução livre: Recomendações para os Sistemas de Liquidação de Títulos e Valores Mobiliários. Disponível em: <http://www.bis.org/publ/cpss46.pdf>. Acesso em: 11/9/2010.

${ }^{129}$ Reccomendation 1. Legal risk: A CCP should have a well founded, transparent and enforceable legal framework for each aspect of its activities in all relevant jurisdictions.

Reccomendation 2. Participation requirements: A CCP should require participants to have sufficient financial resources and robust operational capacity to meet obligations arising from participation in the CCP. A CCP should have procedures in place to monitor that participation requirements are met on an ongoing basis. A CCP's participation requirements should be objective, publicly disclosed, and permit fair and open access.

Reccomendation 3. Measurement and management of credit exposures: A CCP should measure its credit exposures to its participants at least once a day. Through margin requirements, other risk control mechanisms or a combination of both, a CCP should limit its exposures to potential losses from defaults by its participants in normal market conditions so that the operations of the CCP would not be disrupted and non-defaulting participants would not be exposed to losses that they cannot anticipate or control.

Reccomendation 4. Margin requirements: If a CCP relies on margin requirements to limit its credit exposures to participants, those requirements should be sufficient to cover potential exposures in normal market conditions. The models and parameters used in setting margin requirements should be risk-based and reviewed regularly.

Reccomendation 5. Financial resources: A CCP should maintain sufficient financial resources to withstand, at a minimum, a default by the participant to which it has the largest exposure in extreme but plausible market conditions.

Reccomendation 6. Default procedures: A CCP's default procedures should be clearly stated, and they should ensure that the CCP can take timely action to contain losses and liquidity pressures and to continue meeting its obligations. Key aspects of the default procedures should be publicly available. 
- Recomendação 1 (Riscos legais): os intermediários de mercado devem possuir uma estrutura jurídica bem fundada, transparente, efetiva e eficaz para cada aspecto de suas atividades em todas as jurisdições relevantes.

- Recomendação 2 (Requisitos para participação): deve ser exigido dos participantes que tenham recursos financeiros suficientes e capacidade operacional robusta para lidar com obrigações decorrentes de sua participação na operação de intermediação. Os intermediários de mercado devem possuir procedimentos para analisar os requisitos de participação continuamente. Os requisitos de participação devem ser objetivos, amplamente divulgados e também permitir amplo e igual acesso a todos.

- Recomendação 3 (Medição e gerenciamento dos riscos de crédito): o intermediário deve controlar sua exposição de crédito aos seus participantes pelo menos uma vez por dia. Por meio de exigência de margens de garantia, de outros mecanismos de

Reccomendation 7. Custody and investment risks: A CCP should hold assets in a manner whereby risk of loss or of delay in its access to them is minimised. Assets invested by a CCP should be held in instruments with minimal credit, market and liquidity risks.

Reccomendation 8. Operational risk: A CCP should identify sources of operational risk and minimise them through the development of appropriate systems, controls and procedures. Systems should be reliable and secure, and have adequate, scalable capacity. Business continuity plans should allow for timely recovery of operations and fulfilment of a CCP's obligations.

Reccomendation 9. Money settlements: A CCP should employ money settlement arrangements that eliminate or strictly limit its settlement bank risks, that is, its credit and liquidity risks from the use of banks to effect money settlements with its participants. Funds transfers to a CCP should be final when effected.

Reccomendation 10. Physical deliveries: A CCP should clearly state its obligations with respect to physical deliveries. The risks from these obligations should be identified and managed.

Reccomendation 11. Risks in links between CCPs: CCPs that establish links either cross-border or domestically to clear trades should evaluate the potential sources of risks that can arise, and ensure that the risks are managed prudently on an ongoing basis. There should be a framework for cooperation and coordination between the relevant regulators and overseers.

Reccomendation 12. Efficiency: While maintaining safe and secure operations, CCPs should be costeffective in meeting the requirements of participants.

Reccomendation 13. Governance: Governance arrangements for a CCP should be clear and transparent to fulfil public interest requirements and to support the objectives of owners and participants. In particular, they should promote the effectiveness of a CCP's risk management procedures.

Reccomendation 14. Transparency: A CCP should provide market participants with sufficient information for them to identify and evaluate accurately the risks and costs associated with using its services.

Reccomendation 15. Regulation and oversight: A CCP should be subject to transparent and effective regulation and oversight. In both a domestic and an international context, central banks and securities regulators should cooperate with each other and with other relevant authorities. 
controle de riscos ou da combinação de ambos, o intermediário deve limitar seus riscos de potenciais perdas em razão de inadimplementos contratuais de seus participantes em condições normais de mercado, para que suas operações não sejam prejudicadas e também para que os contratantes que não desrespeitaram seus contratos não sejam expostos a perdas que não poderiam ter sido previstas ou controladas.

- Recomendação 4 (Exigência de Margens de Garantia): se um intermediário se utiliza do sistema de exigência de margens de garantia para limitar sua exposição aos riscos de crédito, essa exigência deve ser suficiente para compensar a potencial perda a que está sujeito este intermediário nas condições normais de mercado. Os moldes e parâmetros utilizados para determinar o nível das margens de segurança ou garantia devem ser baseados no risco ao qual o intermediário está exposto, e devem ser revisados periodicamente.

- Recomendação 5 (Recursos Financeiros): o intermediário de mercado deve manter recursos financeiros suficientes para compensar, no mínimo, o inadimplemento de seu participante de maior volume, ou seja, daquele por quem o intermediário expôsse mais. Isto ainda considerando condições extremas de mercado, embora plausíveis.

- Recomendação 6 (Procedimentos em caso de inadimplemento): em caso de inadimplemento, deve haver um procedimento claro a ser adotado, que deve assegurar que o intermediário pode convenientemente agir de forma a conter perdas e manter a liquidez, além de garantir o adimplemento das suas obrigações. Os aspectos-chave dos procedimentos em caso de inadimplemento devem estar disponíveis ao mercado.

- Recomendação 7 (Riscos de Custódia e de Investimento): o intermediário deve manter ativos de tal maneira que o risco de perda ou de atraso no acesso aos mesmos seja minimizado. Ativos investidos pelo intermediário devem ser mantidos em instrumentos com o mínimo de risco de crédito, de mercado e de liquidez. 
- Recomendação 8 (Risco Operacional): o intermediário deve localizar fontes de risco operacional e minimizá-las por meio do desenvolvimento de sistemas apropriados, controles e procedimentos adequados. Os sistemas devem ser confiáveis e seguros, e possuir adequada e escalonada capacidade. Planos de continuidade de negócios devem permitir a conveniente retomada de operações e o cumprimento das obrigações do intermediário.

- Recomendação 9 (Liquidação): o intermediário deve empregar o que estiver em seu poder para eliminar ou estritamente limitar seus riscos de liquidação bancária, ou seja, seu risco de crédito e de liquidez provenientes do uso de bancos para efetuar as liquidações financeiras dos seus participantes. As transferências de fundos devem ser irrevogáveis após seu lançamento.

- Recomendação 10 (Liquidação Física): o intermediário deve estatuir de forma clara suas obrigações em relação às entregas físicas. Os riscos decorrentes dessas obrigações devem ser identificados e gerenciados.

- Recomendação 11 (Riscos nas relações entre intermediários): intermediários que estabelecem ligações com mercados estrangeiros ou mesmo internamente no intuito de realizar negócios mais transparentes devem avaliar as potenciais fontes de risco que podem surgir e se certificar de que os riscos estão sendo continuamente gerenciados com prudência. Deve haver um ambiente propício para a cooperação e coordenação entre reguladores e supervisores relevantes na área.

- Recomendação 12 (Eficiência): enquanto mantêm operações seguras, os intermediários devem satisfazer as exigências dos participantes de maneira eficiente, ou seja, com um bom nível de custo benefício.

- Recomendação 13 (Administração): o regime de administração deve ser claro e transparente para cumprir exigências de interesse público e atender aos objetivos 
dos acionistas e dos participantes. Em particular, devem promover a eficácia dos procedimentos de gestão de riscos do intermediário.

- Recomendação 14 (Transparência): o intermediário deve oferecer aos participantes do mercado informação suficiente para que identifiquem e avaliem eficientemente os riscos e custos associados à utilização de seus serviços.

- Recomendação 15 (Regulação e Supervisão): o intermediário deve ser objeto de regulação efetiva e transparente, assim como de supervisão nestes mesmos moldes. Nacional e internacionalmente, Bancos Centrais e Agências Reguladoras de Mercados de Valores Mobiliários devem cooperar entre si e com outras autoridades relevantes.

Da análise das recomendações supracitadas, percebe-se claramente que o BIS e a IOSCO insistem na importância do efetivo controle das operações pelos intermediários, com vistas a uma melhor administração, distribuição e isolamento dos riscos envolvidos, evitando a contaminação sistêmica em razão de eventuais problemas.

Boa parte do conteúdo das propostas é de caráter subjetivo e, por isso, dá margem a interpretações diversas acerca do atendimento ou não das recomendações pelos reguladores e auto-reguladores.

No âmbito de estudo deste trabalho, cingido às entidades do SPB, o que se pode concluir é que o estado da arte da regulação brasileira das caixas de liquidação está em condições satisfatórias, pois todas as preocupações manifestadas pelo BIS e pela IOSCO estão, se não plenamente resolvidas, muito bem contempladas pela legislação e pelos normativos das clearing houses.

Não foi identificada nenhuma dissonância entre as recomendações BIS/IOSCO e o arcabouço normativo do SPB digna de nota. 


\subsection{CONCLUSÕES GERAIS}

Ao longo da história do empreendedorismo, o empresário sempre teve que assumir riscos, em algum momento do seu negócio ou, no mais das vezes, a todo momento.

Para sobreviver e - mais importante que isso -, para alavancar oportunidades de crescimento futuro, um dos maiores desafios do empresário é conhecer os riscos da sua atividade, para que possa afastá-los, mitigá-los ou simplesmente estar ciente do que está em jogo, conforme a circunstância. Noutras palavras, o risco é inerente à própria atividade empresarial, assim como a necessidade de conhecê-lo e gerenciá-lo.

No caso do sistema financeiro e do mercado de capitais, o risco mais relevante é o legal, que compreende a incerteza de liquidação financeira e a possibilidade de interferência de agentes ou efeitos estranhos ao processo produtivo.

O risco legal foi bem reduzido no Brasil com a Lei do SPB, que inaugurou um cenário de maior segurança e certeza das liquidações financeiras, afastando externalidades antes preocupantes - como os regimes de insolvência - sobre as garantias atreladas às câmaras de liquidação, protegendo seu patrimônio especial.

O legislador brasileiro optou por seguir a linha de raciocínio adotada nas economias mais desenvolvidas, que é a criar sistemas rígidos e eficazes que não só reduzem os riscos de insolvência, mas também os limitam ao segmento econômico daqueles que os criaram.

Procura-se afastar, portanto, a figura do Estado como ente que, em último caso, arcaria com os prejuízos causados pelos particulares. É óbvio que o grau de intervenção estatal sempre é modulado de acordo com os interesses políticos e estratégicos dos governantes, mas o importante é saber que o sistema financeiro está estruturado para se auto-regular e absorver o risco inerente às suas atividades. 
Com esse fim, além de criar o SPB, o legislador brasileiro optou por reforçar a blindagem do patrimônio especial das caixas de liquidação por meio da Lei de Recuperação e Falência, conferindo-lhe proteção específica.

Resolvidas essas questões mais tormentosas para a mínima higidez das liquidações no Sistema Financeiro Nacional, o foco das caixas de liquidação passou a ser o de fazer seu dever de casa: aperfeiçoar ainda mais os mecanismos de gestão e utilização das garantias, otimizando e reduzindo os custos operacionais, sem afetar a segurança do sistema, por meio do isolamento dos riscos setoriais.

Outro desafio é incrementar a segurança das compensações e liquidações internacionais, uma vez que os sistemas financeiros dos diferentes países estão cada vez mais interligados.

Nesse cenário de relações econômicas globais envolvendo não mais somente as grandes corporações, mas também os indivíduos, o que se mostra premente é que os ordenamentos jurídicos devem sofisticar os mecanismos que garantem a higidez dos seus sistemas financeiros, preservando as condições mínimas de atratividade para os investidores e de segurança para todos os cidadãos, para que possam exercer suas atividades com tranqüilidade.

$\mathrm{O}$ grande desafio que o mercado de meios de pagamento tem trabalhado para superar é o de carrear para o sistema financeiro todas as pessoas físicas e jurídicas indistintamente. Idealmente, todos os agentes econômicos de todas as partes do mundo estariam conectados a um só sistema financeiro cross-border.

Enquanto isso não é possível, observa-se que aos poucos novos segmentos da economia vão aderindo a algum sistema de liquidação automatizado de operações financeiras.

Se no início as caixas de liquidação operavam somente com obrigações entre instituições financeiras, aos poucos os negócios entabulados nas bolsas de valores e no mercado de balcão foram sendo entregues às clearings. 
Recentemente foi dada autorização para diversas pessoas jurídicas acessarem diretamente a câmara brasileira de reservas bancárias (STR), para que as mesmas não mais precisassem de um banco intermediário para realizar suas operações envolvendo instituições financeiras diversas.

Outro exemplo que merece ser citado é o da unificação no Brasil das "maquininhas de cartão", como são popularmente conhecidos os equipamentos de recebimento de cartão de crédito e débito, que até meados de 2010 estavam habilitadas para a aceitação exclusiva de uma só bandeira.

Por conta dessa unificação e da conseqüente interoperabilidade dos sistemas de acesso ao crédito dos portadores dos cartões, esse foi mais um segmento econômico que precisou se organizar e aderir a um sistema de liquidação único, acessível a todos os envolvidos.

Esses exemplos demonstram que o aumento do raio de alcance das clearings, em termos de segmentos econômicos e tipos de transações e obrigações liquidadas, é um caminho sem volta.

A liquidação de obrigações financeiras por meio de papel moeda ou título de crédito cambiariforme será exceção, como de fato já o é nas grandes metrópoles do mundo, em se tratando de obrigações mais corriqueiras. Nesses locais, boa parte da população tem fácil acesso aos meios eletrônicos de pagamento e estes, por seu turno, têm larga aceitação por parte dos comerciantes e prestadores de serviço.

Em verdade, no Brasil já não há pessoas residindo em municípios “desbancarizados" $" 130$. Os programas sociais do Governo Federal ${ }^{131}$, inclusive, são pagos mediante depósito em conta específica do beneficiário, que deverá sacar os recursos em caixa eletrônico ou utilizá-los diretamente em estabelecimentos comerciais, tal qual um cartão de débito.

\footnotetext{
130 Termo utilizado pelo BaCen para se referir aos locais em que não há nenhuma representação de instituições financeiras.

${ }^{131}$ Bolsa Família, Bolsa Escola etc.
} 
Nesse contexto, as caixas de liquidação exercem um dos papéis de maior relevância, que é oferecer as condições para o sistema financeiro se apresentar claramente como seguro para os cidadãos, já que credibilidade é a chave.

Conclui-se que o modelo vigente de regulação das caixas de liquidação do Sistema de Pagamentos Brasileiro é condizente com as melhores práticas dos mercados mais relevantes, alinhando-se às recomendações dos organismos multilaterais que estudam a espécie.

Nesse caso, é de suma importância que o legislador, o regulador e, em especial, o auto-regulador, permaneçam vigilantes e dispostos a aperfeiçoar cada vez mais os mecanismos de segurança, eficiência e eficácia do Sistema Financeiro Nacional, para que este, inclusive, sirva de exemplo para a comunidade internacional. 


\section{BIBLIOGRAFIA}

ABECS. Resumo de indicadores 2003/2004. Disponível em: <http://www.abecs.org.br/novo_site/arquivos\%20excel/Tabela_Resumida_2004.pdf>. Acesso em 15/11/2010.

- Indicadores mensais 2010. Disponível em: <http://www.abecs.org.br/novo_site/ arquivos\%20excel/Mensal_2010_Consolidado.pdf>. Acesso em 27/12/2010.

ABRÃO, Nelson. Direito bancário. 12.ed. São Paulo: Saraiva, 2009.

ALVES, Ney Castro. Mercados dinâmicos, princípios eternos. São Paulo: Cultura, 1999.

ANDREZZO, Andréa Fernandes; LIMA, Iran Siqueira. Mercado financeiro - Aspectos históricos e conceituais. São Paulo: Pioneira, 1999.

ARAUJO, Rodolfo. Das operações de bolsa e dos contratos diferenciais. Recife: Imprensa Oficial, 1946.

ASCARELlI, Túlio. Problemas das sociedades anônimas em Direito Comparado. 2.ed. São Paulo: Saraiva, 1969.

AZEVEDO, Laurentino de. Da compensação. São Paulo: Globo, 1920.

BALASUBRAMANIAN, Sathishkumar. Clearing System in Indian Banks. 2009. Disponível na Social Science Research Network: http://ssrn.com/abstract=1457862

BANCO CENTRAL DO BRASIL. Diagnóstico do sistema de pagamentos de varejo no Brasil. Disponível em: <http://www.bcb.gov.br/?SPBINSTPAG>. Acesso em 1/10/2009. 
. Estatísticas do Sistema de Pagamentos Brasileiro. Disponível em: <http://www.bcb.gov.br/?SPBEST>. Acesso em 1/10/2009.

BANCO DAS COMPENSAÇÕES INTERNACIONAIS (BIS). Core principles for systemically important payment systems. 2001. Disponível em: $<$ http://www.bis.org/publ/cpss43.pdf>. Acesso em: 5/9/2009.

. Recommendations for securities settlements systems. 2001. Disponível em: $<$ http://www.bis.org/publ/cpss43.pdf>. Acesso em: 6/9/2009.

BEZERRA FILHO, Manoel Justino. Lei de recuperação e empresas e falências comentada: comentário artigo por artigo. 4.ed. São Paulo: RT, 2007.

CAMPI, Cesare Coltro. I contratti di borsa nella giurisprudenza. Milano: Giuffré, 1988. . Problemi di diritto di borsa. Milano: Giuffré, 1968. . Contratti di borsa al New York Stock Exchange. Milano: Giuffré, 1958.

CANNON, James Graham. Clearing-houses: their history, methods, and administration. Nova York: Appleton, 1908.

CARNELUTTI, Francesco. Teoria giuridica della circolazione. Padova: Cedam, 1933.

CARVALHOSA, Modesto. O caráter normativo dos regulamentos da Comissão de Valores Mobiliários. Revista da CVM, Rio de Janeiro, v.2, n.6, 1984.

CARVALHOSA, Modesto; EIZIRIK, Nelson. A nova Lei das sociedades anônimas. São Paulo: Saraiva, 2002.

CCCC. The clearings - early days. Disponível em: <http://www.chequeandcredit.co.uk/information/-/page/the_clearings_-_early_days/>. Acesso em 16/8/2010. 
COASE, Ronald Harry. The firm, the market and the law. Chicago: University of Chicago Press, 1990.

COFFEE, John C. et alli. Securities regulation cases and materials. 8.ed. New York: Foundation Press, 1998.

COMMITTEE OF EUROPEAN SECURITIES REGULATORS. Standards for Securities Clearing and Settlement Systems in Europe. 2004.

COMPARATO, Fábio Konder. As ações de sociedade anônima como valores mobiliários - natureza e efeitos do registro acionário. Novos Ensaios e Pareceres de Direito Empresarial, Forense, Rio de Janeiro, 1981.

. Natureza jurídica das bolsas de valores e delimitação de seu objeto. Revista de Direito Mercantil, Industrial, Econômico e Financeiro, São Paulo, v.60. O seguro de crédito. São Paulo: RT, 1968.

CORDEIRO FILHO, Ari. Swaps - aspectos jurídicos, operacionais e administrativos. Rio de Janeiro: Forense Universitária, 2000.

CORRADO, Renato. I contratti di borsa. Torino: Unione Tipografico-Editrice Torinense, 1950.

DE LUCCA, Newton. As bolsas de valores e os valores mobiliários. Revista TRF-3 ${ }^{a}$ Região, São Paulo, v.35.

DINIZ, Maria Helena. Curso de direito civil brasileiro: teoria geral das obrigações. 21.ed. São Paulo: Saraiva, 2006.

DUFFIE, Darrell; ZHU, Haoxiang. Does a Central Clearing Counterparty Reduce Counterparty Risk? Rock Center for Corporate Governance at Stanford University Working Paper, n. 46, 2009. Disponível na Social Science Research Network: http://ssrn.com/abstract=1348343 
DUTRA, Marcos Galileu Lorena. As novas estruturas organizacionais das bolsas. 2008. 230f. Dissertação (Mestrado em Direito) - Programa de Pós-Graduação em Direito Comercial, Universidade de São Paulo, São Paulo, 2008.

EDWARDS, Franklin R.; MA, Cindy W. Futures and options. Singapore: McGraw-Hill, 1992.

EIZIRIK, Nelson. Aspectos jurídicos dos mercados futuros. Revista de Direito Mercantil, Industrial, Econômico e Financeiro, São Paulo, n.81.

. Instituições financeiras e mercado de capitais: jurisprudência. Rio de Janeiro: Renovar, 1996.

. Reforma das S/A e do mercado de capitais. Rio de Janeiro: Renovar, 1998.

EUROCLEAR. The Single Settlement Engine (2005) and Subsequent Business Model Deliverables. Consultation Paper, 2005.

EUROPEAN COUNCIL AND PARLIAMENT. Clearing and Settlement in the European Union - The Way Forward. Communication, 2004.

FERNANDES, Antônio Alberto Grossi. O sistema financeiro nacional comentado. São Paulo: Saraiva, 2006.

FERREIRA, Luis Eduardo Martins. As bolsas de valores no Brasil. Revista de Direito Mercantil, Industrial, Econômico e Financeiro, São Paulo, n.86.

FIGUEIREDO, Rafael Paganotti; ARTES, Rinaldo. A evolução do sistema de pagamentos brasileiro e o desaparecimento do cheque: realidade ou exagero? INSPER Working Paper 136/2008. Disponível em: <http://www.insper.edu.br/sites/default/files/2008_ wpe136.pdf>. Acesso em 12/12/2010. 
FOLHA DE SÃO PAULO. Citi volta ao ramo de cartões dois anos após vender Redecard (Elavon). 29/12/2010.

FONTAINE, Henri. La bourse et ses operations legales. 3.ed. Paris: A Pedonem 1905.

FORGIONI, Paula Andrea. A evolução do Direito Comercial brasileiro: da mercancia ao mercado. São Paulo: RT, 2009.

FORTUNA, Eduardo. Mercado financeiro - produtos e serviços. 16ed. Rio de Janeiro: Qualitymark, 2006.

GALBRAITH, John Keneth. A short history of financial euphoria. New York: Penguim, 1994.

GALGANO, Francesco. Diritto privato. Padova: Cedam, 1992.

GIOVANNINI GROUP. Cross-border Clearing and Settlement Arrangements in the European Union. Bruxelas: 2001.

. Second report on EU Clearing and Settlement Arrangements.Bruxelas, 2003.

GOMES, Orlando. Contratos. 23.ed. Rio de Janeiro: Forense, 2001.

GORGA, Érica Cristina R. A importância dos contratos a futuro para a economia de mercado. Revista de Direito Mercantil, Industrial e Industrial Econômico e Financeiro, RT, São Paulo, no 112.

GRAU, Eros Roberto; FORGIONI, Paula. O Estado, a empresa e o contrato. São Paulo: Malheiros, 2005.

GUERREIRO, José Alexandre Tavares. Sobre o poder disciplinar da CVM. Revista de Direito Mercantil, Industrial, Econômico e Financeiro, São Paulo, n.43. 
HASENPUSCH, Tina P. Clearing services for global markets: a framework for the future development of the clearing industry. Cambridge: 2009.

HOBSBAWN, Eric. A era das revoluções. 12.ed. São Paulo: Paz e Terra, 2000. . A era do capital. 5.ed. Rio de Janeiro: Paz e Terra, 2000.

IBGE. Estimativa populacional em 1/7/2003. Disponível em: <ftp://ftp.ibge.gov.br/ Estimativas_Projecoes_Populacao/Estimativas_2003/>. Acesso em 5/1/2011.

Censo Demográfico 2010. Disponível em: $<$ http://www.ibge.gov.br/servidor_arquivos_est/diretorios.php?caminho=./pub/Censos/Cen so_Demografico_2010\#>. Acesso em 5/1/2011.

JANTALIA, Fabiano (org.). A regulação jurídica do Sistema Financeiro Nacional. Rio de Janeiro: Lumen Juris, 2009.

JONES, Robert A.; PERIGNON, Christophe. Derivatives Clearing and Systemic Risk. 2009. European Financial Data Institute 12/2008 meeting. Disponível na Social Science Research Network: http://ssrn.com/abstract=1095695

KROSZNER, Randall S. Can the Financial Markets Privately Regulate Risk? The Development of Derivatives Clearing Houses and Recent Over-the-Counter Innovations. 1999. Disponível na Social Science Research Network: http://ssrn.com/abstract=170350.

LANNOO, K.; LEVIN, M. The securities settlement industry in the EU - structure, costs and the way forward. Bruxelas: Centre for European Policy Studies, 2001.

LE GOFF, Jacques. Mercadores e banqueiros da Idade Média. São Paulo: Martins Fontes, 1991.

LEÃES, Luiz Gastão Paes de Barros. Estudos e pareceres sobre sociedades anônimas. São Paulo: RT, 1989. 
. Liquidação compulsória dos contratos futuros. Revista dos Tribunais, São

Paulo, n.675, 1992.

LEVY, Maria Bárbara. História da bolsa de valores do Rio de Janeiro. Rio de Janeiro: IBMEC, 1977.

LINCIANO, Nadia; SICILIANO, Giovanni; TROVATORE, Gianfranco. The Clearing and Settlement Industry: Structure, Competition and Regulatory Issues. 2005. Disponível na Social Science Research Network: http://ssrn.com/abstract=777508

LORUSSO, Ettore. Le borse valori. Milano: Giuffré, 1972.

MAJELLO, Ugo. Custódia e depósito. Napoli: Eugenio Jovene, 1958.

MANDELL, Lewis. The Credit Card Industry: A History. Boston: Twayne Publishers, 1990.

MATTOS FILHO, Ary Oswaldo. A natureza jurídica das bolsas de valores. Revista da CVM, Rio de Janeiro, 1985, v.3, n.7.

MAZZONE, Rosario. Gli accordi di compensazione: nel commercio interno e nel commercio Internazionale. Bari: Luigi Macri, 1936.

McPARTLAND, John. Clearing and settlement demystified. Chicago: Chicago FED Letter: 2004.

MESSINEO, Francesco. Operazioni di borsa e di banca: studi giuridici. 2.ed. Milano: Giuffrè, 1954.

MILLS, Annie. Essential strategies for financial services compliance. Chichester (UK): John Wiley and Sons, 2008.

MOSQUERA, Roberto Quiroga (org.). Aspectos Atuais do direito do mercado financeiro e de capitais. São Paulo: Dialética, 2000. 
NIELSSON, Ulf. Clearing and Settement of Derivatives: Is a Code-of-Conduct Advisable? European Law Journal, 6/2009. Disponível na Social Science Research Network: <http://ssrn.com/abstract=1427435>. Acesso em: 12/12/2010.

NIEUWENHUIJZEN. Financial Law in the Netherlands. Alphen: Kluwer Law International, 2010.

NODA, Margareth. Acesso eletrônico e tendências para a intermediação no mercado de valores mobiliários. 92f. Dissertação (Mestrado em Direito) - Programa de Pós-Graduação em Direito Comercial, Universidade de São Paulo, São Paulo, 2010.

OLIVEIRA, Fernando Albino de. Poder regulamentar da Comissão de Valores Mobiliários. Tese de doutoramento para a Universidade de São Paulo, São Paulo, 1989.

PEREIRA, Mozart Emygdio. A bolsa e o direito. Bolsa Oficial de Valores de São Paulo, 1950.

PLANIOL, Marcel. Traité élémentaire de droit civil. v.2. 6.ed. Paris: Libraire général de droit \& de jurisprudence, 1912-1915.

PONTES DE MIRANDA, Francisco Cavalvanti. Tratado de Direito Privado. Rio de Janeiro: Borsoi, 1955.

PEREIRA FILHO, Valdir Carlos. Clearing Houses: Aspectos jurídicos relevantes e seu papel no mercado de capitais e no sistema de pagamentos brasileiro. Revista de Direito Bancário e do Mercado de Capitais, São Paulo, v. 27, pp. 64-83, 2005.

REUTERS BRASIL. First Data será nova concorrente de Redecard e Cielo. 1/7/2010.

ROCHA, Bolívar B. M. O poder normativo de órgãos da administração - o caso da comissão de valores mobiliários. Revista de Direito Mercantil, Industrial, Econômico e Financeiro, São Paulo, n.64. 
ROPPO, Enzo. O contrato. Coimbra: Almedina, 1998.

RUSSO, Daniela; HART, Terry L.; SCHÖNENBERGER, Andreas. The Evolution of Clearing and Central Counterparty Services for Exchange-Traded Derivatives in the United States and Europe: A Comparison. 2002). European Central Bank Occasional Paper, n.5. Disponível na Social Science Research Network: <http://ssrn.com/abstract=748968>. Acesso em: 10/12/2010.

SACCO, Rodolfo; DE NOVA, Giorgio. Il contrato. 3.ed. Torino: UTET, 2004.

SADDI, Jairo. Crise e regulação bancária - Navegando mares revoltos. São Paulo: Textonovo, 2001.

SALLES, Marcos Paulo de Almeida. Comentários e sugestões ao ante-projeto de lei das sociedades anônimas. São Paulo: Acrefi, 1975.

. O contrato futuro. São Paulo: Cultura, 2000.

. Mercado de valores mobiliários e Comissão de Valores Mobiliários. São Paulo: Resenha Universitária, 1980.

SALOMÃO FILHO, Calixto. Regulação da atividade econômica. São Paulo: Malheiros, 2001.

SALOMÃO NETO, Eduardo. Direito bancário. São Paulo: Atlas, 2005. . O trust e o direito brasileiro. São Paulo: LTR, 1996.

SCHUMPETER, Joseph A. Teoria do desenvolvimento econômico. Uma investigação sobre lucros, capital, crédito, juro e o ciclo econômico. Trad. Maria Silvia Possas. Os Economistas. Nova Cultural: 1997.

SERIFSOY, Baris; WEISS, Marco. Settling for Efficiency - A Framework for the European Securities Transactions Industry. Frankfurt: Goethe University, 2007. 
SIENKIEWICZ, Stan. Credit Cards and Payment Efficiency. Federal Reserve Bank of Philadelphia. Discussion Paper. Agosto/2001. Disponível em: $<$ http://www.philadelphiafed.org/payment-cards-center/publications/discussion-papers/ 2001/PaymentEfficiency_092001.pdf>. Acesso em 1/12/2010.

SILVA, Clóvis V. do Couto e. A obrigação como processo. São Paulo: FGV, 2008.

SIMÕES, Raul Humberto de Lima. Das caixas de liquidação: organismos complementares das bolsas de mercadorias. Lisboa: 1934.

SOUZA JÚNIOR, Francisco Satiro de. Regime jurídico das opções negociadas em bolsas de valores. 2002. 185f. Tese (Doutorado em Direito) - Programa de Pós-Graduação em Direito Comercial, Universidade de São Paulo, São Paulo, 2002.

. Comentários sobre os artigos 193 e 194. In: SOUZA JÚNIOR, Francisco Satiro de; PITOMBO, Antônio Sérgio A. de Moraes (Orgs.). Comentários à Lei de recuperação de empresas e falência. São Paulo: RT, 2006. pp. 591-599.

SZTAJN, Rachel. Contratos de bolsa. In: Novos contratos empresariais. São Paulo: RT, 1990.

. O paradoxo do sistema financeiro. $245 \mathrm{p}$. Tese apresentada no concurso de professor titular do Departamento de Direito Comercial da Faculdade de Direito da Universidade de São Paulo. Universidade de São Paulo, São Paulo, 2009.

- Sobre a natureza jurídica das opções negociadas em bolsas. Separata do Boletim da Faculdade de Direito de Coimbra, v. LXXII, 1996.

TÁCITO, Caio. Parecer sobre o poder regulamentar do Conselho Monetário Nacional e da Comissão de Valores Mobiliários. Revista da CVM, Rio de Janeiro, 1986, v.4, n.12.

TEIXEIRA, Egberto Lacerda. Os Cartões de Crédito Bancário. Revista de Direito Mercantil, São Paulo, 8/122. 
TEIXEIRA, Marco Aurélio. Mercados futuros - fundamentos e características operacionais. São Paulo: BM\&F, 1992.

THE DEPOSITORY TRUST \& CLEARING CORPORATION. Annual Report 2009. Disponível em: <http://www.dtcc.com/downloads/annuals/2009/2009_report.pdf>. Acesso em 13/12/2010.

THE NEW YORK CLEARING HOUSE ASSOCIATION. New York Clearing House Historical Perspective. Disponível em: <http://www.theclearinghouse. org/docs/000591.pdf>. Acesso em 17/8/2010.

THRALLS, Jerome. The clearing house. Nova York: American Bankers Association, 1916.

VALOR ECONÔMICO. Mais uma estrangeira disputa filão de cartões (Global Payments). 4/1/2011.

VEIGA, Alexandre Brandão da. As fases de negociação e de liquidação e compensação de operações de bolsa a contado. Direito dos Valores Mobiliários, Coimbra, 1999, v.1.

VEIGA FILHO, João Pedro da. Bolsa de café - Câmara syndical, caixa de liquidação e classificação em Santos (parecer). São Paulo: Duprat, 1907.

VERÇOSA, Haroldo Malheiros Duclerc. Bancos Centrais no Direito Comparado - O Sistema Financeiro Nacional e o Banco Central do Brasil (O regime vigente e as propostas de reformulação). São Paulo: Malheiros, 2005.

- Os regimes políticos e jurídicos dos bancos centrais. In: Direito da integração. São Paulo: Cultural Paulista, 2001.

Responsabilidade civil especial dos administradores e controladores das instituições financeiras e nos consórcios em liquidação extrajudicial. São Paulo: RT, 1993. 
; BARRETO FILHO, Oscar. Vade-mécum do mercado de capitais. São Paulo: Saraiva, 1978.

VIVANTE, Cesare. Instituições de direito comercial. Lisboa: Clássica, 1918.

WALD, Arnoldo. Estudos e pareceres de Direito Comercial. São Paulo: RT, 1992.

; EIZERIK, Nelson. O regime jurídico das bolsas de valores e sua autonomia frente ao estado. Revista de Direito Mercantil, Industrial, Econômico e Financeiro, São Paulo, n.61. 